\title{
OPEN Morphological and immunohistochemical phenotype of TCs in the intestinal bulb of Grass carp and their potential role in intestinal immunity
}

\author{
Hanan H. Abd-Elhafeez $\mathbb{1}^{1 凶}$, Alaa S. Abou-Elhamd $\mathbb{1}^{1}$ \& Soha A. Soliman $\mathbb{(}^{2}$
}

The current study investigated telocytes (TCs) in the intestinal bulb of Grass carp using light microscopy (LM), Transmission electron microscopy (TEM), scanning electron microscopy, and immunohistochemistry (IHC). By LM, TCs were distinguished by the typical morphological features that had a cell body and telopodes using $\mathrm{HE}$, toluidine blue, methylene blue, Marsland silver stain, Grimelius's silver nitrate, Giemsa, PAS, combined AB pH2,5/PAS, Crossmon's and Mallory triple trichrome, Van Gieson stains, Verhoeff's stain, Sudan black, osmic acid, performic acid with methylene blue and bromophenol blue. TCs were identified under the epithelium as an individual cell or formed a TCs sheath. They detected in the lamina propria, between muscle fibers, around the myenteric plexus and fibrous tissue. TCs acquired immunological features of endocrine cells that exhibited high affinity for silver stain, performic acid with methylene blue, Marsland stain, and immunohistochemical staining using chromogranin A. Sub epithelial TCs were closely related to the endocrine cells. TCs and their secretory activities were recognized using acridine orange. TCs were identified by IHC using CD34, CD117, S100-protein, desmin. TCs formed a3D network that established contact with macrophage, mast cells, dendritic cells, lymphocytes, smooth muscle fibers, fibroblast, Schwann cells and nerve fibers. In conclusion, the localization of TCs in relation to different types of immune cells indicated their potential role in the maintenance of intestinal immunity.

Interstitial cells have critical roles in the maintenance of the appropriate $3 \mathrm{D}$ scaffold and functional requirements of the organs. Telocytes (TCs) are the cell population that forms a network through a labyrinthine system formed by telopodes. They are long and slender prolongations reached up to hundreds of microns. Telopodes are identified by their segments; the thin segment, podomer and the thick segment, the podoms. TCs established contact to other resident cells or to wandering cells via their telopodes or via the cell body. Telopodes network provide-long-distance cell-cell signaling (intercellular communication) ${ }^{1}$.

Paracrine signaling is critical for TCS function. TCs produce several secretory molecules and factors contributing to the functional significance.Gene analysis ${ }^{2}$ and proteomics analysis ${ }^{3}$ are investigated for TCs. The functional contributions of TCS are supposed to be related to angiogenesis ${ }^{4}$, and development, maintenance of homeostatic balance ${ }^{4}$, immunosurveillance ${ }^{5}$, tissue regeneration and repair through providing adequate microenvironment for stem cell niche and promoting their differentiation ${ }^{6,7}$.

TCs are identified in a wide variety of organs from diverse species including mammals ${ }^{8-11}$, avian ${ }^{12,13}$, reptiles ${ }^{14}$, Amphibians ${ }^{15}$ and aquatic species ${ }^{16,17}$ and parasitic worm ${ }^{18}$. They are located in the trachea and lungs ${ }^{19}$, heart $^{20}$ and the blood vessels ${ }^{21}$, kidney, ureter, urinary bladder ${ }^{22}$, tongue ${ }^{23}$, oesophagus, stomach and small and large intestines ${ }^{24}$, liver , pancreas ${ }^{14}$, testis ${ }^{25}$, prostate ${ }^{26}$, efferent ductules ${ }^{27}$ ovaries, oviducts, uterus, vagina, mammary glands and placenta ${ }^{26}$, spleen $^{8,28}$.

${ }^{1}$ Department of Anatomy, Embryology and Histology, Faculty of Veterinary Medicine, Assiut University, Assiut 71526, Egypt. 2Department of Histology, Faculty of Veterinary Medicine, South Valley University, Qena 83523, Egypt. ${ }^{\circledR}$ email: hhnnzz91@aun.edu.eg 


\begin{tabular}{|c|c|c|}
\hline Fixative & Components & Amount \\
\hline \multirow{3}{*}{ Bouin's solution } & Parafomaldehyde $40 \%$ & $25 \mathrm{~mL}$ \\
\hline & Saturated picric acid & $75 \mathrm{~mL}$ \\
\hline & Glacial Acetic acid & $5 \mathrm{~mL}$ \\
\hline \multirow{4}{*}{ Karnovsky fixative } & Paraformaldehyde, $25 \%$ freshly prepared & $10 \mathrm{~mL}$ \\
\hline & Glutaraldehyde $50 \%$ & $10 \mathrm{~mL}$ \\
\hline & Na-Phosphate buffer (0.1 M, pH 7.4) & $50 \mathrm{~mL}$ \\
\hline & Distilled water & $30 \mathrm{~mL}$ \\
\hline \multirow{9}{*}{ N a-Phosphate buffer (0.1 M, pH 7.4) } & Solution A & \\
\hline & $\mathrm{Na}_{2} \mathrm{HPO}_{4 \cdot 2} \mathrm{H}_{2} \mathrm{O}$ Disodium hydrogen phosphate & $17.02 \mathrm{gm}$ \\
\hline & Distilled water & $600 \mathrm{~mL}$ \\
\hline & Solution B & \\
\hline & $\mathrm{NaH}_{2} \mathrm{PO}_{4} 2 \mathrm{H}_{2} \mathrm{OSodium}$ dihydrogen phosphate & $6 \mathrm{gm}$ \\
\hline & Distilled water & $200 \mathrm{~mL}$ \\
\hline & Using solution & \\
\hline & \begin{tabular}{|l|} 
Solution A \\
\end{tabular} & $580 \mathrm{~mL}$ \\
\hline & Solution B & $219 \mathrm{~mL}$ \\
\hline \multirow{10}{*}{ Citrate-buffer (pH 6.0) } & Solution A & \\
\hline & Citric acid monohydrate $\mathrm{C}_{6} \mathrm{H}_{8} \mathrm{O}_{7} \cdot \mathrm{H}_{2} \mathrm{O}$ & $21 \mathrm{~g}$ \\
\hline & Distilled water & $1 \mathrm{~L}$ \\
\hline & \begin{tabular}{|l|} 
Solution B \\
\end{tabular} & \\
\hline & Sodium citrate $\mathrm{Na}_{3} \mathrm{C}_{6} \mathrm{H}_{5} \mathrm{O}_{7} .2 \mathrm{H}_{2} \mathrm{O}$ & $29.41 \mathrm{~g}$ \\
\hline & Distilled water & $1 \mathrm{~L}$ \\
\hline & Using solution & \\
\hline & Solution A & $9 \mathrm{~mL}$ \\
\hline & Solution B & $41 \mathrm{~mL}$ \\
\hline & Distilled water & Add $500 \mathrm{~mL}$ \\
\hline
\end{tabular}

Table 1. Components of the fixative.

TCs immunoprofile is recognized in several species. CD34/PDGFRa is specific markers for TCs ${ }^{29}$. TCs express other markers such as desmin, vimentin, SMA, tubulin, VEGF, and others ${ }^{8,27}$. The current study investigates the distribution, morphology, immunohistochemical characterization of TCs in the intestinal bulb of Grass carp.

\section{Material and methods}

Sample collection. The present work was carried out on eight specimens of adult grass carp or white amur (Ctenopharyngodon idella) (Order: Cypriniformes, Family: Cyprinidae) with the average mean standard length was $36.40 \pm 3.01 \mathrm{~cm}$, and the mean standard body mass was $506.40 \pm 9.60 \mathrm{~g}$.

All fish were anaesthetized using benzocaine $(4 \mathrm{mg} / \mathrm{L})$ and decapitated. The gastrointestinal tract was carefully excised after abdominal incision. The intestinal bulb, an anterior intestinal dilatation, was obtained and incised to wash and remove the mucous coat of the mucosal surface.

Four fish were taken for light microscopic examination, two fish for Scanning electron micrograph, and two fish transmission electron microscopic examination.

Sample fixation and processing. Light microscopic examination. Fixation and processing of samples of paraffin-embedded samples for conventional and histochemical staining. Samples from the intestinal bulb were fixed in Bouin's solution (Table 1). Samples were processed according to the description by ${ }^{30}$ as the following: The fixed samples thoroughly washed in $70 \%$ ethanol $(3 \times 24 \mathrm{~h})$ to get rid of the fixative before subsequent processing. The samples were dehydrated in ascending grades of alcohol (80\%, 90\%, 100I, 100\% II), cleared in methyl benzoate, and then embedded in paraffin wax for three hrs. Serial transverse and longitudinal sections of 5-7 $\mu \mathrm{m}$ were prepared by using a Richert Leica RM 2125 Microtome, Germany. For general histological examination, paraffin representative sections were stained by Hematoxylin and Eosin satin ${ }^{31}$.

Histochemical investigation. The following histochemical stain used was cited in $^{32}$ : trichrome according to Crossmon's ${ }^{33}$ and Mallory triple trichrome stain ${ }^{34}, \mathrm{PAS}^{35}$, Combined Alcian Blue $\mathrm{pH}$ 2.5 Periodic acid Schiff (AB pH 2.5 /PAS) technique ${ }^{36}$, Wiegert ${ }^{37}$, Verhoeff's counter stain by Van Gieson ${ }^{38}$, Long ziehl neelsen, Giemsa stain, Grimelius's silver nitrate ${ }^{39}$ and Marsland. Gless and Erikson method ${ }^{40}$.

All staining methods were cited by ${ }^{32}$

Leitz Dialux 20 Microscope provided with a Canon digital camera (Canon Power shot A95) used to examine the stained sections and capture the images. 


\begin{tabular}{|c|c|c|c|c|c|c|}
\hline Target & Primary antibody supplier & Origin (catalog no) & Dilution & Incubation & Antigen retrieval & $\begin{array}{l}\text { Secondary antibody- } \\
\text { incubation time }\end{array}$ \\
\hline CD34 & $\begin{array}{l}\text { Rat Anti-mouse CD34 } \\
\text { antibody ( e bioscience, San } \\
\text { Diego, CA) }\end{array}$ & $\begin{array}{l}\text { mouse CD34 Monoclonal } \\
\text { Antibody (Clone: RAM34) } \\
\text { (Cat.no 14-0.341-85) }\end{array}$ & $1: 100$ & Over night & $\begin{array}{l}\text { Boiling in citrate buffer } \\
\text { (pH 6.0), } 20 \mathrm{~min} \\
\text { Goat }\end{array}$ & \multirow{2}{*}{$\begin{array}{l}\text { Biotinylated goat Anti- } \\
\text { Polyvalent, Anti-mouse } \\
\text { Igg + Anti-Rabbit Igg, } \\
\text { Thermo Fisher Scientific, } \\
\text { The UK. Lab Vision Corpo- } \\
\text { ration; USA } \\
\text { One hour at room tem- } \\
\text { perature }\end{array}$} \\
\hline CD117 (Kit) & $\begin{array}{l}\text { Anti-CD117 (e Bioscience, } \\
\text { San Diego, CA) }\end{array}$ & $\begin{array}{l}\text { Mouse Cd117 Monoclonal } \\
\text { Antibody } \\
\text { (Clone. ACK2) } \\
\text { (Cat. no. 14-1172-82) }\end{array}$ & $1: 100$ & Over night & $\begin{array}{l}\text { Boiling in citrate buffer } \\
\text { (pH 6.0), } 20 \mathrm{~min}\end{array}$ & \\
\hline S100 protein & $\begin{array}{l}\text { Anti-S100 protein (Dako, } \\
\text { Glostrup, Denmark; }\end{array}$ & $\begin{array}{l}\text { Rabbit polyclonal Anti- } \\
\text { bodycode No. Z0311 }\end{array}$ & $1: 100$ & Overnight & $\begin{array}{l}\text { Boiling in citrate buffer } \\
\text { (pH 6.0), } 20 \mathrm{~min}\end{array}$ & \multirow{3}{*}{$\begin{array}{l}\text { Goat anti-rabbit secondary } \\
\text { antibody (cat. no. K4003, } \\
\text { Envision + TM System } \\
\text { Horseradish Peroxidase } \\
\text { Labelled Polymer; Dako) } \\
30 \text { min at room temperature }\end{array}$} \\
\hline Chromogarnin A & $\begin{array}{l}\text { Anti Chromogranin } \\
\text { A-(Dako A0430) }\end{array}$ & $\begin{array}{l}\text { Polyclonal, Rabbit anti- } \\
\text { Human }\end{array}$ & $1: 1000$ & $\begin{array}{l}\text { One hour at room tem- } \\
\text { perature }\end{array}$ & $\begin{array}{l}\text { boiling in citrate buffer }(\mathrm{pH} \\
6.0), 20 \mathrm{~min}\end{array}$ & \\
\hline Desmin & $\begin{array}{l}\text { Thermo Fischer scientific } \\
\text { (invitrogen) }\end{array}$ & $\begin{array}{l}\text { Desmin recombinant rabbit } \\
\text { monoclonal antibody } \\
\text { Clone (sI18-00) } \\
\text { Cat.MA5-32,068 }\end{array}$ & $1: 50$ & $\begin{array}{l}\text { One hourat room tem- } \\
\text { perature }\end{array}$ & $\begin{array}{l}\text { Boiling in citrate buffer } \\
\text { (pH 6.0), } 20 \mathrm{~min}\end{array}$ & \\
\hline
\end{tabular}

Table 2. Identity, sources, and working dilution of antibodies used in immunohistochemical studies. Antibodies used that showed reactivity in fish species in past publication.

Osmium tetroxide paraffin procedure for fat. After fixation of a small piece about $0.0 .5 \times 0.5 \times 0.5 \mathrm{~cm}$ sample in $10 \%$ Neutral buffer formalin, they placed in osmium tetroxide for demonstration of fat by the method that allows paraffin embedded in the tissue [Connective and Muscle Tissue ${ }^{41-43}$ ] .

Acridine orange (fluorescent stain). The procedure was performed according to that of Hoff et al. modified by Refs. ${ }^{27,44-48}$. Acridine Orange is a cationic dye and stains proteins-containing membranous vesicles including secretory vesicles, membrane bounded acidic compartments, and lysosomes that had an acidic nature. Acridine Orange exhibits a metachromatic reaction that associated with the liberation of green and red fluorescence. Acridine Orange reacts with the membrane bounded vesicles and appeared orange or red. Acridine Orange is used for the identification of secretory vesicles and lysosomes ${ }^{49-51}$.

The stained sections analyzed using a Leitz DM 2500 microscope with the external fluorescent unit Leica EL 6000 .

Immunohistochemistry staining (IHC) for CD34, CD117. Immunohistochemically staining was performed on paraffin sections .Antigen localization was achieved using combined with the avidin-biotin complex (ABC) technique ${ }^{52}$. Using the Reagent of Ultra Vision Detection System (Anti-Polyvalent, HRP/DAB (ready to use, TP-015-HD: Thermo Fischer Scientific TP-015HD) according to the manufacturer's instructions. The procedure according to a description of ${ }^{53}$ as the following:

Paraffin sections of $(5 \mu \mathrm{m})$ were dewaxed by xylene, rehydrated by ascending grades of alcohols, and rinsed by PBS pH 7.4 (3 times for $5 \mathrm{~min}$ ). Endogenous peroxidase was suppressed by using a hydrogen Peroxide block at room temperature. The sections were thoroughly washed by running tap water for an additional $10 \mathrm{~min}$. To enhance antigen retrieval, the slides were treated with $10 \mathrm{mM}$ sodium citrate buffer (Table 1) (pH 6.0) at a temperature reached 95-98 in a water bath for $20 \mathrm{~min}$. The sections were cooled for $20 \mathrm{~min}$ from room temperature and subsequently were washed in PBS ( $\mathrm{pH} 7.4,3$ times for $5 \mathrm{~min}$ ). Block non-specific background staining was performed by using Ultra V block (Thermo Fisher scientific, UK. Lab Vision corporation; USA) for 5 min at room temperature. Ultra $V$ block application did not exceed $10 \mathrm{~min}$ to avoid staining artifact). The sections were incubated with the primary antibodies (The used primary antibody, sources, dilutions, and time of incubation of each antibody are shown in (Table 2). Sections were washed using PBS (at pH 7.4, 3 times for 5 min). The Biotinylated secondary antibody was applied for one hour at room temperature. The (Table 2). Sectioned were washed in PBS (pH 7.4, 3 times for $5 \mathrm{~min}$ ) and subsequently incubated with streptavidin- peroxidase complex ,Thermo Fisher Scientific, UK. Lab Vision corporation; USA) for $10 \mathrm{~min}$ at room temperature. Visualization of the bound antibodies was performed using 1 drop of DAB plus chromogen to $2 \mathrm{~mL}$ of DAB plus substrate. The mixture was applied and incubated at room temperature for $5 \mathrm{~min}$. The incubation processes were carried out in a humid chamber. Harris hematoxylin was used as counter stained for $30 \mathrm{~s}$. The sections were dehydrated using ethanol and isopropanol I and II, cleared in xylene, and covered by DPX.

Use a Leitz Dialux 20 Microscope provided by a cannon digital camera (Cannon Power shot A95) to examine the stained section.

Immunohistochemical procedures of Desmin, S100 protein, chromogranin A. A Technique using the reagent of The DAKO En Vision TM + System, HRP peroxidase. The DAKO Envision TM + System, HRP is a two-step immunohistochemical staining technique ${ }^{54}$.

The procedure of staining according to ${ }^{55}$ used the following protocol: sections $(5 \mu \mathrm{m})$ of paraffin-embedded sections were dewaxed, rehydrated, and rinsed in PBS, pH 7.4 (3 times for $5 \mathrm{~min}$ ). Endogenous peroxidase was inhibited by adding drops of 3\% hydrogen peroxide in methanol at room temperature for 20 min followed by intense washing under running tap water for an additional $10 \mathrm{~min}$. For antigen retrieval, slides were placed in 
$10 \mathrm{mM}$ sodium citrate buffer ( $\mathrm{pH}$ 6.0) (Table 1) and heated to 95-98 in a water bath for $20 \mathrm{~min}$, followed by cooling for $20 \mathrm{~min}$ at room temperature. Sections were then rinsed in PBS ( $\mathrm{pH} 7.4,3$ times $\times 5 \mathrm{~min}$ ). Sections were covered by adding drops of blocking serum (Dako) to cover the sections for $5 \mathrm{~min}$ at room temperature to block non-specific background staining. (Note: Do not exceed $10 \mathrm{~min}$ or there may be a reduction in the desired stain.). Sections were then incubated with the primary antibody (Table 2: Identity, sources, and working dilution of antibodies used in immunohistochemical studies). After incubation, slides were washed with PBS ( $\mathrm{pH} 7.4,3$ times $\times 5 \mathrm{~min}$ ). Followed by incubation for $30 \mathrm{~min}$ at room temperature with secondary antibody at room temperature. The slides were thereafter rinsed in PBS ( $\mathrm{pH} 7.4,3$ times for $5 \mathrm{~min}$ ) followed by Incubation for 5-10 min at room temperature with 3,3'-diaminobenzidine (DAB) + substrate-chromogen which results in a brown-colored precipitate at the antigen site. The sections were counterstained with Harris Hematoxylin were used as a counters stained for $30 \mathrm{~s}$. The sections were dehydrated using ethanol alcohol $90 \%$, and $100 \%$ II, cleared in xylene, and covered by DPX and I Leitz Dialux 20 Microscope provided by a cannon digital camera (Canon Power shot A95) was used to examine immunohistochemical staining.

All Negative controls of the five markers were performed as the previous steps without adding the primary antibody.

Electron microscopic examination. A different small specimen about $3 \mathrm{~mm}^{3}$ thickness was carefully excised and fixed in a Karnovsky fixative ${ }^{56}$ (Table 1) for preparation for scanning electron microscope and transmission electron microscope examination.

Preparations of resin embedding samples for semi thin and ultrathin sections. Abdel-Hafeez and Soliman ${ }^{57}$, Soliman, Ahmed et al. ${ }^{58}$, Soliman and Emeish ${ }^{59}$, Soliman ${ }^{60}$ described the procedure as follows: the samples were washed four times for $15 \mathrm{~min}$ in $0.1 \mathrm{M}$ sodium phosphate buffer $(\mathrm{pH} 7.2)$ and then postfixed in $1 \%$ osmic acid in $0.1 \mathrm{M}$ sodium phosphate buffer at $4^{\circ} \mathrm{C}$ for $2 \mathrm{~h}$. The samples were then washed again three times for $20 \mathrm{~min}$ in $0.1 \mathrm{M}$ phosphate buffer ( $\mathrm{pH}$ 7.2). Dehydration was performed by using ethanol gradient and propylene oxide. Samples were dehydrated in an ascending graded ethanol series [50\% (for $30 \mathrm{~min}$ ), 70\% (overnight), 90\% (for $30 \mathrm{~min}$ ), 100\% I (for $30 \mathrm{~min}$ ), and 100\% II (for $60 \mathrm{~min}$ ]. The dehydrated samples were embedded in resin (EponAraldite as follows: propylene oxide (Merck, Darmstadt, Germany for $30 \mathrm{~min}$, Epon: propylene oxide (approximately 1:1, for $30 \mathrm{~min}$ ), followed by Epon (for $3 \mathrm{~h}$ ). Epon was prepared as follows: $5 \mathrm{~mL}$ of Epon 812 (Polysciences, Eppelheim, Germany) $+5 \mathrm{~mL}$ of Araldite $+12 \mathrm{~mL}$ of DDSA. Then, the Epon was mixed thoroughly by incubation in a shaker at $60^{\circ} \mathrm{C}$. Sample polymerization was performed using Epon mix and an accelerator (DMP30) (1.5\%). The blocks were incubated for 3 days as follows: $60^{\circ} \mathrm{C}$ on the first day, $70^{\circ} \mathrm{C}$ on the second day, and $75^{\circ} \mathrm{C}$ on the third day.

Using an Ultra cut E (Reichert Leica RM2125, Microtome, Germany), 0.5-1 $\mu \mathrm{m}$ thick semi-thin sections were cut. The semi-thin sections were stained with toluidine blue $\mathrm{e}^{32}$.

Ultrathin sections were obtained from semi-thin sections by a Reichert ultra-microtome. The sections $(70 \mathrm{~nm})$ were stained with uranyl acetate and lead citrate ${ }^{61}$ and examined by JEOL100CX II transmission electron microscope at the Electron Microscopy Unit of Assiut University.

Semi-thin sections stained by PAS stain. Additional resin-embedded specimens were used in PAS stain. Resin sections were treated with a saturated alcoholic solution of sodium hydroxide for 3 min to dissolve the resin ${ }^{62}$. Then processed the methods as usual PAS stain after immersion in ethanol alcohol $100 \%, 90 \%, 80 \%, 70 \%$ for $3 \mathrm{~min}$ in each concentration. The protocol used in the preparation of semi-thin sections was performed according to references ${ }^{8,32}$.

Digital coloring of scanning and transmission electron microscopic images. We applied digital coloring for the transmission electron microscopic images using the Photo Filter 6.3.2 program to identify different types of cells and structures. Many authors previously used the methods ${ }^{12,63-67}$.

CMEIAS color segmentation (for supplementary images). Negative images were performed using CMEIAS Color Segmentation, an improved computing technology used to process color images by segmenting the foreground object of interest from the background ${ }^{64}$. This has been done by the following steps: open the image with CMEIAS Color Segmentation, then select "Process" from the menu items, and subsequently choose "Negative image" $68-71$.

Ethical approval. The National ethics committee of Assiut University and veterinary authorities -from Assiut province, Egypt, were approved the method of work. "All methods were performed in accordance with the relevant guidelines and regulations".

\section{Results}

The current study investigated TCs in the intestinal bulb of the Grass carp. The intestinal bulb consisted of epithelium, lamina propria, muscular layer, serosa (Fig. 2A). Light microscope (LM), Transmission electron microscope (TEM), Scanning electron microscope (SEM), and immunohistochemistry (IHC) recognized Telocytes (TCs). For light microscopic examination, their typical morphological features distinguished TCs that had a cell body contained the nucleus and telopodes. TCs recognized by H\&E (Fig. 3A,B) and toluidine blue blue (Fig. 5A-F). They had high affinity for nervous tissue-specific staining; methylene blue (Fig. 1A-E), Marsland silver stain (Fig. 2A-G), Grimelius's silver nitrate impregnation (Fig. 4B,C) and Giemsa (Fig. 4E,F). TCs had strong affinity 


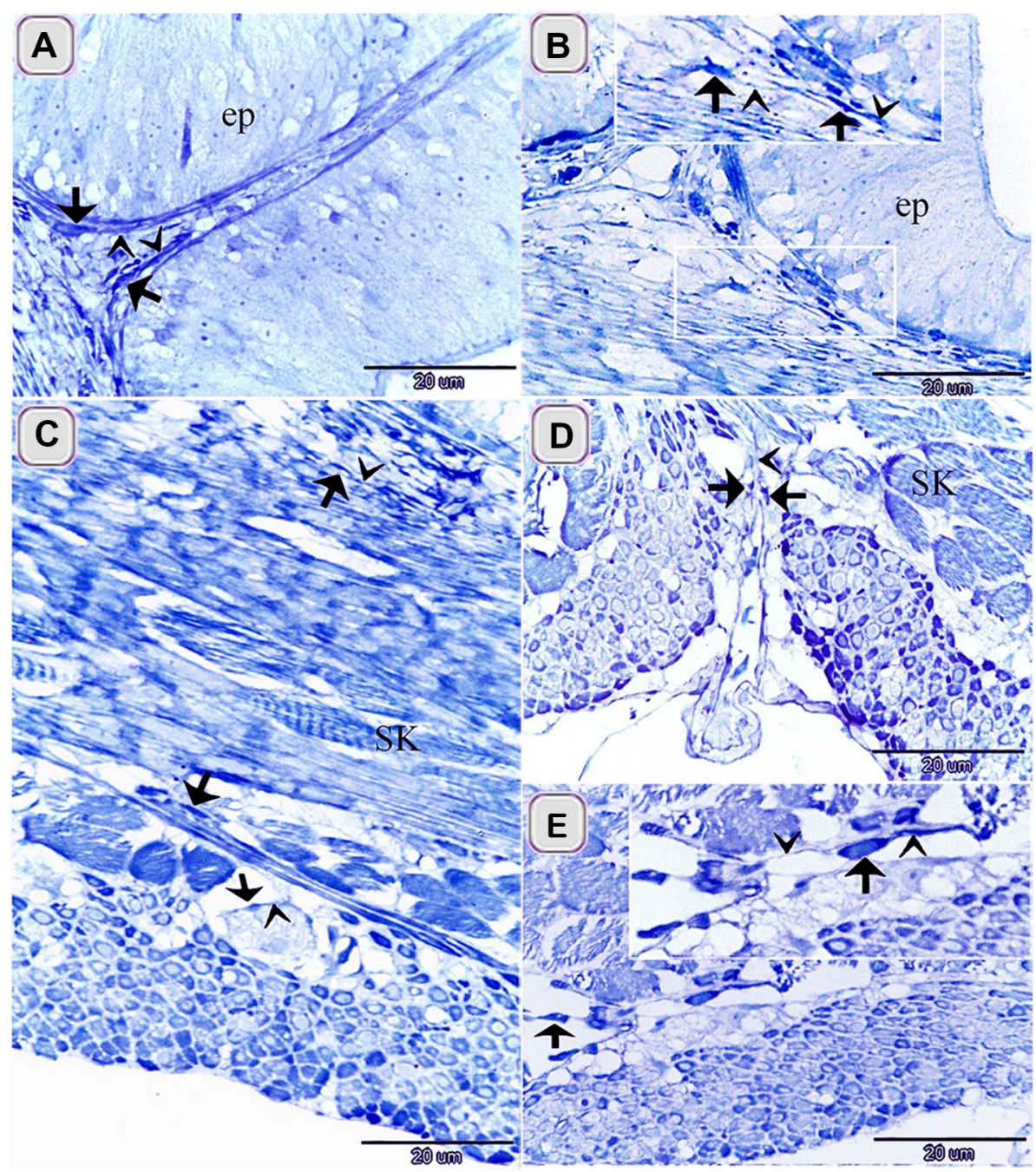

Figure 1. Identification of TCS in the intestinal bulb of Grass carp using methylene blue. Semi thin sectioned of the intestinal bulb stained by methylene blue. The cell body of TCs (arrows), telopodes (arrowheads) under the epithelium (A), in the lamina propria (B) and in between the muscular fibers (C-E). Note epithelium (ep), skeletal muscles (SK) in the initial part of intestinal bulb.

for PAS (Fig. 3C), combined AB ph2.5 /PAS stain (Fig. 3D), took the affinity of PAS only. They had a strong affinity for collagen fiber-specific stains including Light green (Fig. 3E,F), Methyl blue (Fig. 3G). While Tc tend to stain by Verhoeff stain (Fig. 4D) and exhibited a reaction similar to elastic fibers rather than collagen fibers when stained by Combined Weigert counter by Van Gieson stain and Van Gieson (Fig. 4G,H). They were visible in paraffin sections stained by Sudan black (Fig. 3H) and osmic acid (Fig. 3I). They stained for protein-specific stain performic acid with Methylene blue and bromophenol blue (Figs. 4I, 6C)

TCs were located under the epithelium as an individual cell (Figs. 1A,2D,3G, H, 4A, B,5A-C) or formed a TCs sheath (Figs. 2 B, C, E, 3D), lamina propria (Figs. 1B,3A, C, F, I,4D-F, I, 5A-C), between muscle fibers (Figs. 1,2F, G, 4C, G, H), between muscle bundles (Figs. 1C-E, 5 E, F), around the myenteric plexus (Fig. 3B, E) and fibrous tissue (Fig. 5C).

TCs acquired immunological features of endocrine cells. Relation between TCs and epithelial and interstitial endocrine cells was recognized using Grimelius's silver nitrate stain (Fig. 6A-c),, performic acid with methylene blue((Fig. 6D), Marsland stain (Fig. 6G,H) and Immunohistochemical staining using chromogranin A (Fig. 6E,F,I).Chromogranin A positive TCs in the lamina propria (Fig. 6F,I). The Negative images were represented as a supplementary figure (supplementary Fig. 6).

TCs and their secretory activities were recognized using Acridine orange. They were distributed under the epithelium in the (Fig. 7D,F), in the lamina propria (Fig. 7A,C,E,G,H), in the muscular layer (Fig. 7B).

Localization of TCs in the intestinal blub of Grass carp was confirmed by Immunohistochemical staining. CD34 positive TCs were detected in the sub epithelial layer (Fig. 8A), around the blood vessels in the lamina propria (Fig. 8B). The Negative images were represented as a supplementary figure (supplementary Fig. 1). 


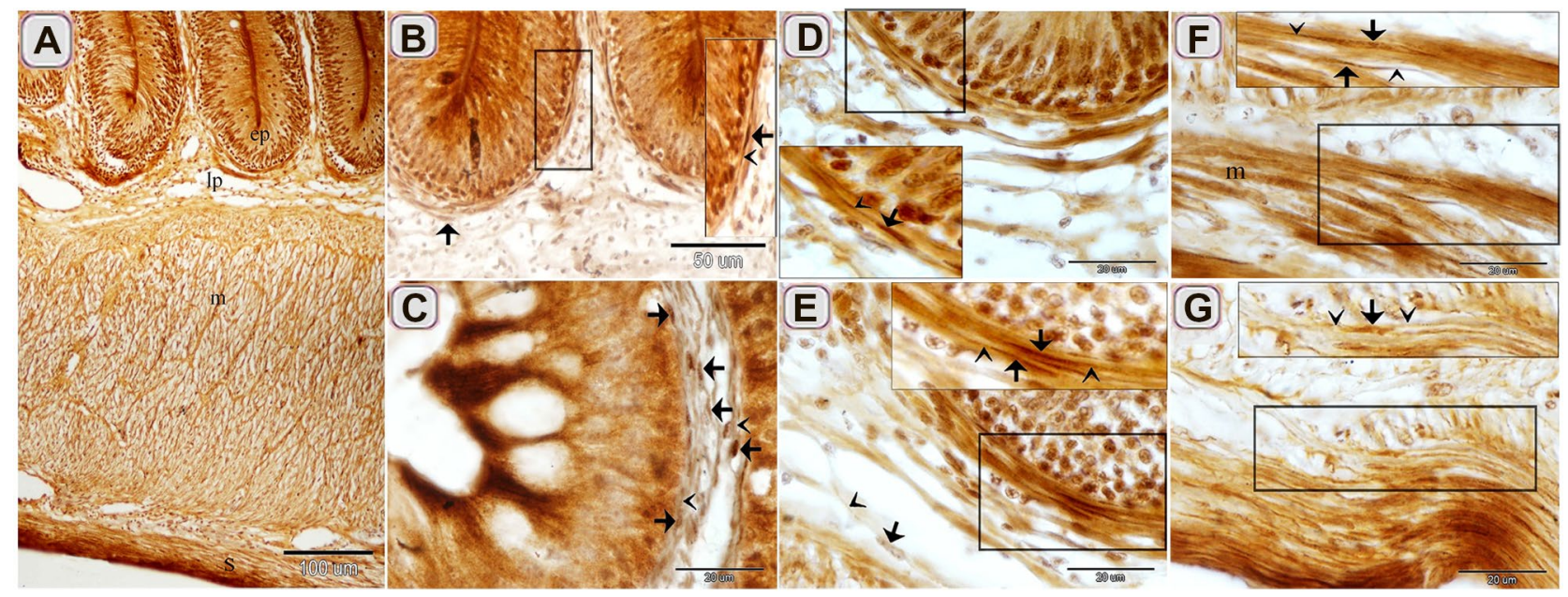

Figure 2. Identification of Telocytes in the intestinal bulb of Grass carp using Marsland silver stain. Paraffin sections of the intestinal blub stained by Marsland silver stain. (A) General histological picture of the intestinal bulb. Note epithlium (ep), lamina propria (lp), muscular layer (m), and serosa (s). (B, C, E) The cell body of TCs (arrows) formed a subepithelial sheath. Telopodes (arrowheads). (D) The cell body of the subepithelial TC (arrow). Telopodes (arrowheads). (F, G) The cell body of the intramuscular TC (arrow). Note muscle $(\mathrm{m})$. Telopodes (arrowheads).

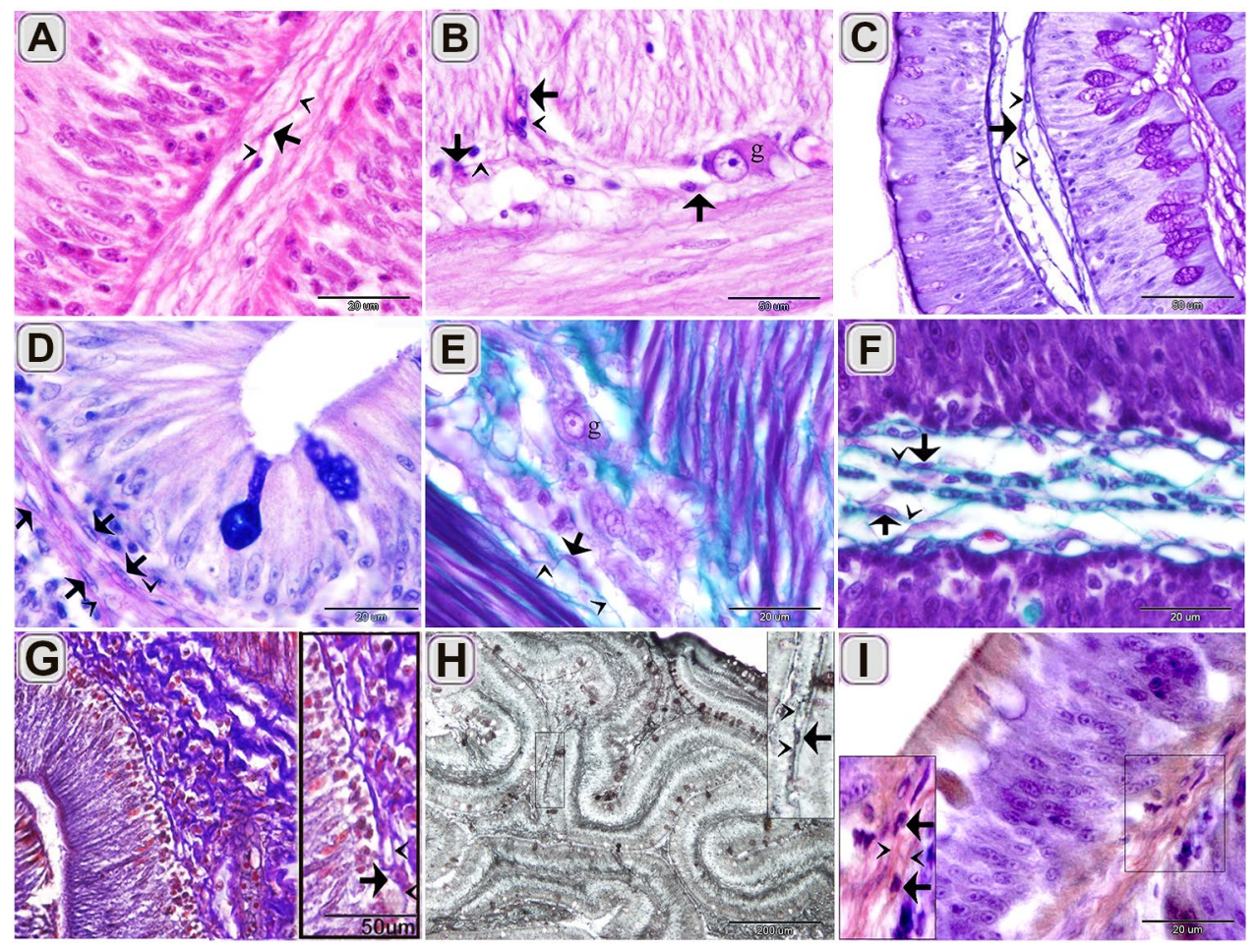

Figure 3. Recognition of TCs using HE, PAS, AB pH 2.5/PAS, Crossmon trichrome, Mallory triple trichrome , Sudan black, osmic acid. Paraffin sections of the intestinal blub stained by $\mathrm{HE}(\mathbf{A}, \mathbf{B}), \mathrm{PAS} / \mathrm{Hx}(\mathbf{C}), \mathrm{AB}$ ph 2.5/ PAS (D), Crossmon trichrome (E, F), Mallory triple trichrome (G), Sudan black (H), osmic acid (I). (A) The cell body of TC (arrow) in the lamina propria was recognized by telopodes. Telopodes (arrowheads). (B) The cell body of TCs (arrows) around the ganglionic cell (g) of the myenteric plexus. Telopodes (arrowheads). (C) TC stained positively for PAS. Telopodes (arrowheads). (D) TC had a strong affinity for PAS rather than AB. Telopodes (arrowheads). (E) The cell body of TCs (arrows) stained green by Crossmon trichrome. Note the ganglionic cell (g) of the myenteric plexus. (F) TC (arrow) in the lamina propria stained green by crossmon trichrome. Telopodes (arrows). (G) The cell body of TCs (arrows) stained blue by Mallory triple. Telopodes (arrowheads). (H) The cell body of TC (arrow) stained black by Sudan black. Telopodes (arrowheads). (I) The cell body of TC (arrow) stained brown by osmic acid. Telopodes (arrowheads). 


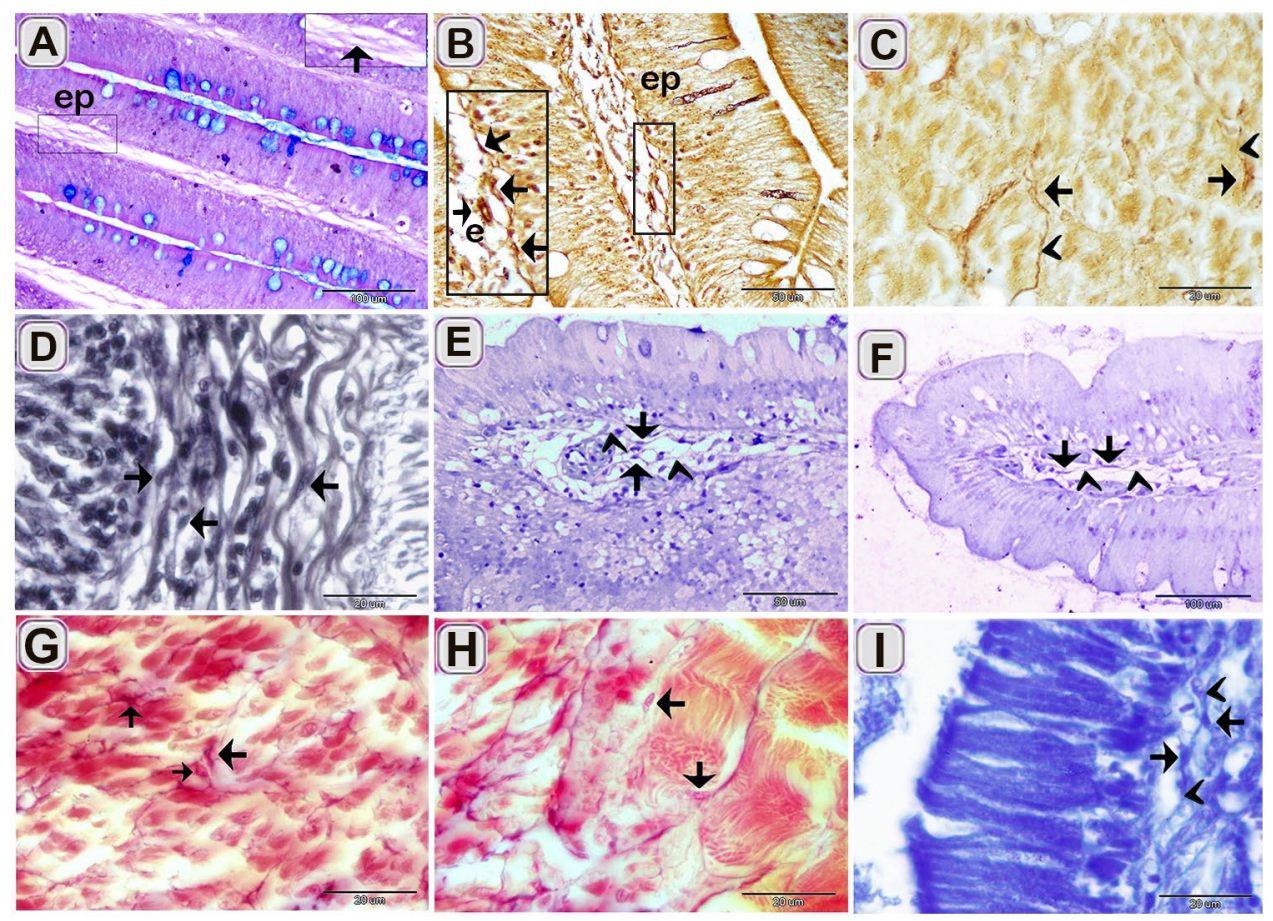

Figure 4. Recognition of TCs using Grimelius's silver nitrate, Verhoeff stain, Giemsa, Weigert Van Gieson, bromophenol blue. Paraffin sections of the intestinal blub stained by Long ziehl neelsen (A), Grimelius's silver nitrate (B, C), Verhoeff stain (D), Giemsa (E, F), Weigert van Gieson (G, H), bromophenol blue (I). (A) The cell body of subepithelial TC (arrow) stained bluish color that had affinity for Methylene blue. Note epithelium (ep). (B) The cell body of the subepithelial Telocytes (arrows) in closed vicinity to endocrine cell (e,arrow). Note epithelium (ep). (C) The cell body of TCs (arrows) located between muscles cells. Telopodes (arrowheads). (D) TC (arrow) stained black by Verhoeff stain. (E, F) TC (arrow) stained blue by Giemsa. Telopodes (arrowheads). $(\mathbf{G}, \mathbf{H})$ TC (arrow) stained positive for Van Gieson. Telopodes (arrowheads). (I) TC stained positive for bromophenol blue. Telopodes (arrowheads).

CD117 positive TCs were detected under the epithelium (Fig. 9A,B), in the lamina propria (Fig. 9A,C,E,F), between MSF (Fig. 9G-I) and around the myenteric plexus. (Fig. 9D). The Negative images were represented as a supplementary figure (supplementary Fig. 2).

TCs exhibited immunohistochemical staining affinity for S100-protein in the lamina propria (Fig. 10D), between the muscle bundles (Fig. 10E), between the muscle fibers (Fig. 10F). Desmin positive TCs were identified in under the epithelium (Fig. 10A), in the lamina propria (Fig. 10B), and between the muscle bundles (Fig. 10C). The Negative images were represented as a supplementary figure (supplementary Fig. 3).

Chromogranin A positive TCs were detected in the lamina propria (Fig. 6E,F,I). The Negative images were represented as a supplementary figure (supplementary Fig. 6).

The images of the negative control were represented as a supplementary figure (supplementary Figs. 4, 5, 7 and 8 ).

TCs established a 3D network that connected with different types of immune cells including macrophages (Figs. 11A-D, 12C,D), mast cells (Figs. 11A,B,D,F, 12A-D), dendritic cells (Fig. 11C-E), lymphocyte (Fig. 11D,E). They also formed contact with smooth muscle fibers (Figs. 11A-C, F, 12A,C,D), fibroblast (Fig. 11D), Schwann cells (Fig. 11D,E) and nerve fibers (Figs. $11 \mathrm{D}-\mathrm{F}, 12 \mathrm{~A}$ ).

By Transmission electron microscope (TEM), TCs connected with mast cells, smooth muscle fibers, nerve fibers (Fig. 12A,B). Subepithelial TCs established a 3D network that connected with macrophages, mast cells, and smooth muscle fibers (Fig. 12C,D).

By Scanning electron microscope (SEM), Sub epithelial TC may form a continuous sheet (Fig. 13B,C). TCs were distributed in the lamina propria (Fig. 13A) where they connected to rodlet cells (Fig. 13D-F). TCs formed a network in the lamina propria (Fig. 14A-C). They were also identified between muscle bundles (Fig. 14D-G, I) and in the serosa (Fig. 14H).

The relation of TCs with endocrine and immune cells was summarized in the illustration figure (Fig. 15).

\section{Discussion}

The current study investigated the distribution, morphology, immunohistochemical characterization of TCs in the intestinal bulb of Grass carp.

We distinguished TCs using a light microscope that had typical morphological features that had a cell body contained the nucleus and telopodes. TCs affinity for nervous tissue-specific staining (methylene blue, Marsland silver stain , silver impregnation, and Giemsa), collagen fiber-specific stains (Crossmon trichrome, Mallory triple, 


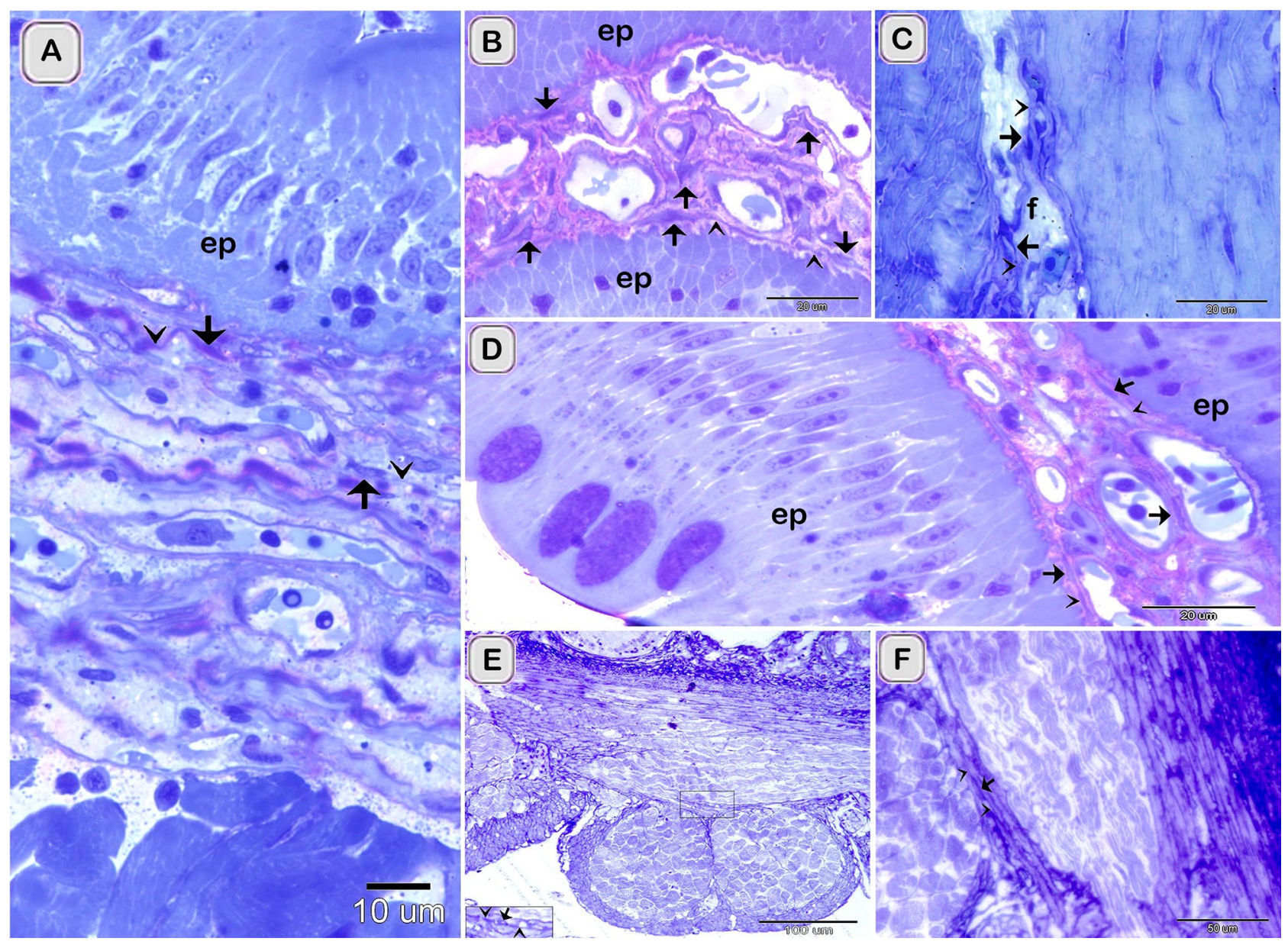

Figure 5. Recognition of TCs using semi thin sections. Semi thin sections stained by toluidine blue. (A, B, D) The cell body of TCs (arrows) under epithelium (ep) and in the lamina propria. Telopodes (arrowheads). (C) The cell body of TCs (arrows) in the fibrous tissue (f). Telopodes (arrowheads). (E, F) The cell body of TCs (arrow) located between the muscle fibers and bundles. Telopodes (arrowheads).

Weigert Van Gieson), polysaccharides-specific stain (PAS,AB pH2.5/PAS) and protein stain (the bromophenol blue) is discussed by Ref. ${ }^{8}$. Methylene blue, Marsland silver stain , silver impregnation stained cytoskeletal elements in the TCs. Cytoskeletal inclusions are stained by methylene blue ${ }^{72}$, Marsland silver stain ${ }^{73}$, silver impregnation $^{74}$. TCs exhibited a strong affinity for carbohydrate staining such as PAS and combined PAS/AB, which revealed neutral polysaccharides. Telocytes had the affinity of protein-detecting stains. They stained positive for bromophenol blue and performic acid with Methylene blue. Proteomic profile analysis is performed for lung TCs, which categorized the functional implications of protein, involved in metabolic processes, cellular processes including cell communication, cytokinesis, cellular component movement, cell cycle. Some proteins implicated in developmental processes including anatomical structure, morphogenesis, mesoderm development, system development, and ectoderm development. Other proteins are linked to localization processes such as vesicle mediated transport, protein transport, and ion transport ${ }^{3}$. TCs had strong staining affinity for Sudan black and osmic acid. This may regard to the lipid components of the TCs cell membrane.

In the current study, TCs were located under the epithelium as an individual cell or formed TCs in the lamina propria, between muscle fibers, between muscle bundles, around the myenteric plexus and in the fibrous tissue. The distribution of TCs in the intestinal bulb of the Grass carp was similar to other tubular organs in mammals. In the bovine uterine tubes, TCs are located under the epithelium forming a subepithelial sheath as well as three other sheath; an outer perimuscular, inner perimuscular and intramuscular sheath. TCs are also distributed in the lamina propria, between the SMF and in the serosa ${ }^{8}$. In chicken ileum, ICC subtypes are mentioned according to location. ICC-MY surrounds the myenteric ganglia. ICC-DMP organized in the deep muscular plexus parallel to the circular muscle bundles. ICC-LP is located in the lamina propria ${ }^{75}$. In murine's GIT, ICC surround the myenteric plexus (Auerbach's plexus) and these are called interstitial cells of Cajal of the myenteric plexus (ICC-MY or ICC-MP) or interstitial cells of Cajal of the Auerbach's plexus [ICC-AP]). Interstitial cells of Cajal of connective tissue septa (ICC-SEP) occur in the connective tissue septa. Intramuscular interstitial cells of Cajal (ICC-IM) are interstitial cells of Cajal of the circular muscle (ICC-CM) and interstitial cells of Cajal of the longitudinal muscle (ICC-LM). Interstitial cells of Cajal of the deep muscular plexus (ICC-DMP) locate in the deep muscular plexus. Interstitial cells of Cajal of the submucosa (ICC-SM) and interstitial cells of Cajal 

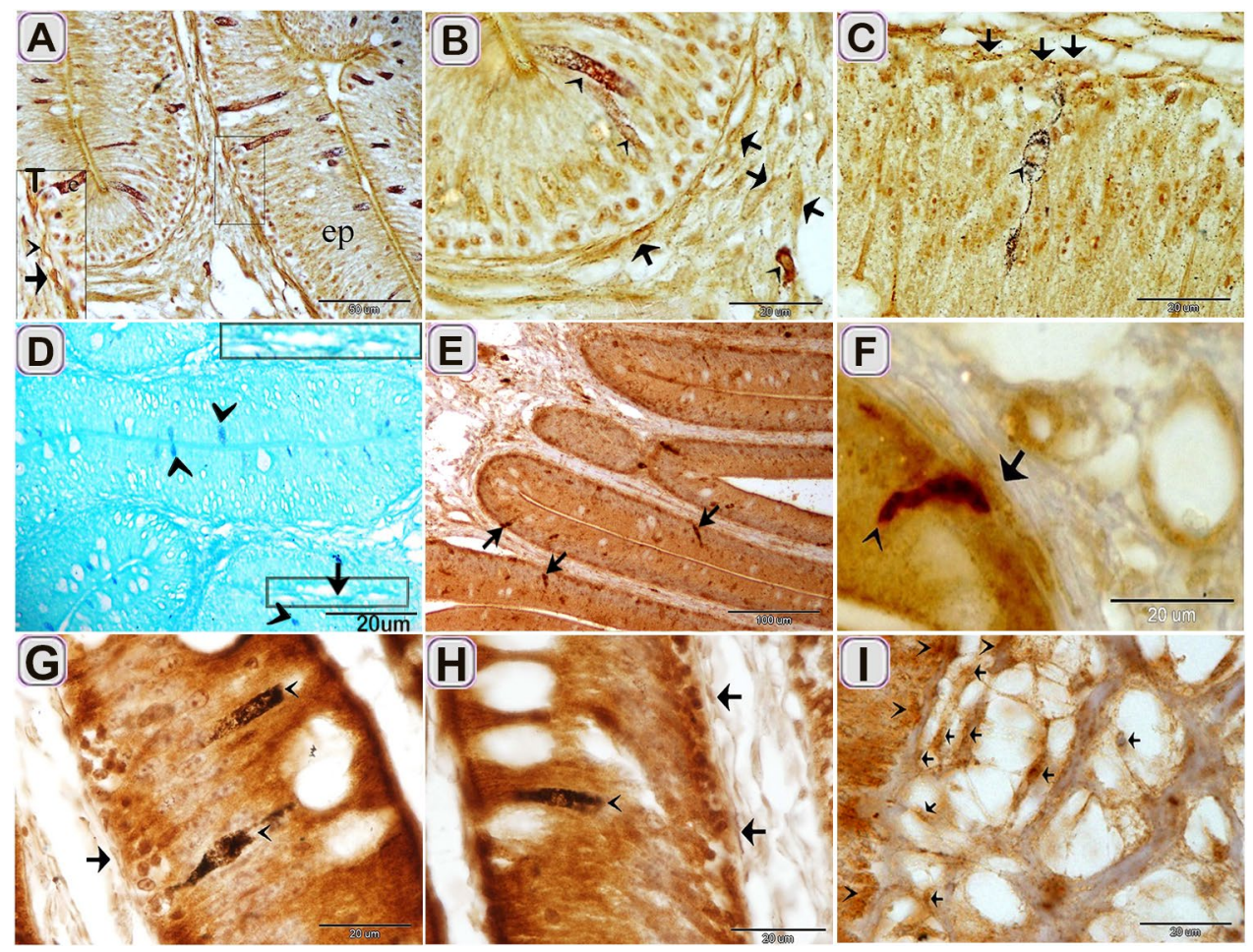

Figure 6. Relation between TCs and epithelial and interstitial endocrine cells using Grimelius's silver nitrate stain, performic acid with methylene blue, Marsland stain, and immunohistochemical staining using chromogranin A. Paraffin sections stained by Grimelius's silver nitrate stain, (A-C), performic acid with alcian blue (D), Marsland stain (G, H), chromogranin A (E, F, I). (A-C) subepithelial TCs (T, arrows) were closely related to endocrine cells (arrowheads). (D) subepithelial TCs (arrows) were closely related to endocrine cells (arrowheads). (E) chromogranin positive cells within the lining epithelium (arrows). (F, G, H, I) subepithelial and interstitial TCs (arrows) were closely related to endocrine cells (arrowheads).

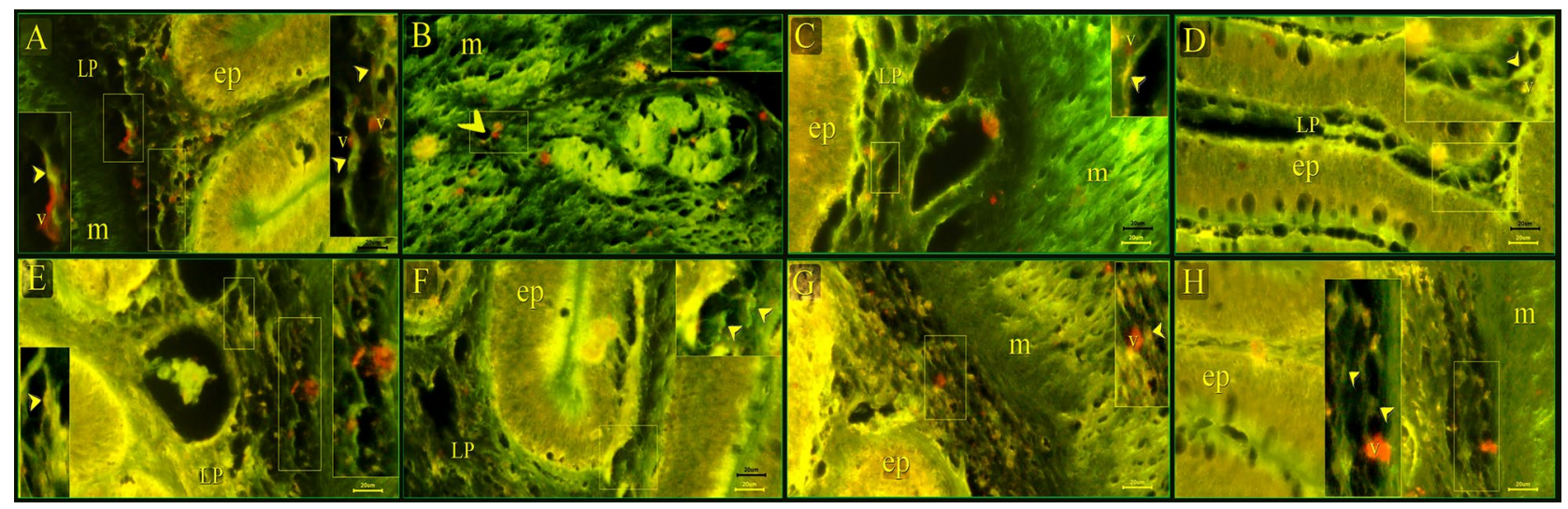

Figure 7. Recognition of TCs using Acridine orange. (A, C, E, G, H) TC in the lamina propria (arrowhead). Note secretory vesicle (v) associated with TC. (B) intramuscular TC (arrowhead). Note the secretory vesicle (v) associated with TC. (D, F) subepithelial TC (arrowhead). Note secretory vesicle (v) associated with TC.

of the submucosal plexus (ICC-SMP) occur in the submucosa and submucosal plexus, respectively. ICC of the subserosa locates in the subserosa ${ }^{76,77}$.

CD-34 is frequently used as a marker for TCs in mammalian and fish species ${ }^{17,27}$. CD34 is a transmembrane phosphoglycoprotein that commonly identified in hematopoietic stem cells and is detected in other progenitor cells such as interstitial cell progenitors, muscle satellite cells, epithelial progenitors, corneal keratocytes, and vascular endothelial progenitors ${ }^{78}$.

TCs expressed chromogranin A that is a highly acidic secretory glycoprotein and is expressed by most neuroendocrine cells. Chromogranin A is closely associated and packed with neurotransmitter peptides and 


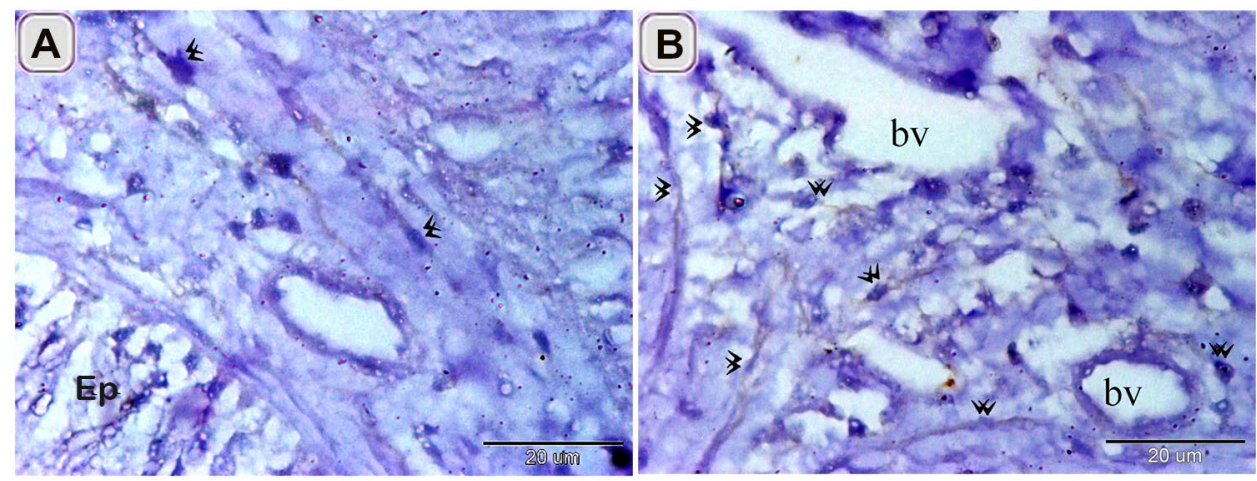

Figure 8. Immunohistochemical staining of the intestinal blub using CD34. Immunostained paraffin sections of the intestinal blub for CD34. counter stain by HX A: CD34 TCs (double arrowheads) in the subepithelial layer (Ep). B: CD34 TCs (double arrowheads) around the blood vessels (bv).
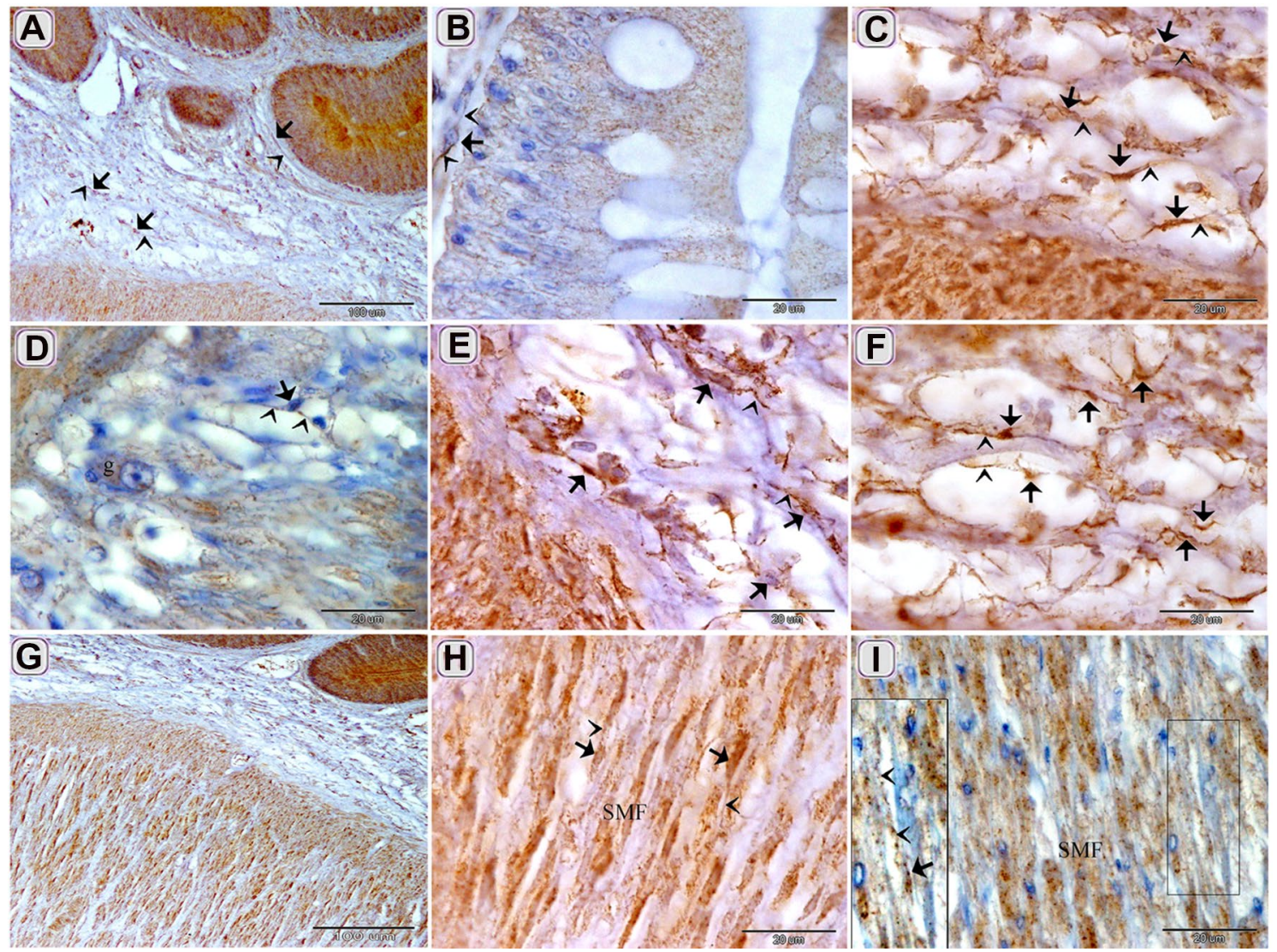

Figure 9. Immunohistochemical staining of the intestinal blub using CD117 counterstain by Hx except figure $\mathrm{H}$. Immunostained paraffin sections of the intestinal blub for CD117. (A) CD117 positive TCs (arrows) under the epithelium and in the lamina propria. (B) CD117 positive sub epithelial TC (arrows). (C, E, F) CD117 positive TCs (arrows) in the lamina propria. (D) CD117 positive TC (arrows) around the ganglionic cell (g) of the myenteric plexus. (G, H I) CD117 positive TC (arrows) within the muscle layers. Note: Telopodes (arrowheads) and smooth muscle fiber (SMF).

monoamines in secretory granules or synaptic vesicles ${ }^{79}$. Chromogranin A involved in the initiation and regulation of biogenesis of secretory granules and sequestration of hormones in neuroendocrine cells ${ }^{80}$.

TCs established direct contact with different types of immune cells in the intestinal blub of the Grass carp. They were connected to mast cells, dendritic cells, and lymphocytes indicating a contribution in the immune response of the intestinal bulb. TCs-immune cells contact occurs as uniform or multicontact synapses that resemble juxtacrine cell-to-cell signaling sites or chemical synapses. Different types of immune cells are mentioned in 


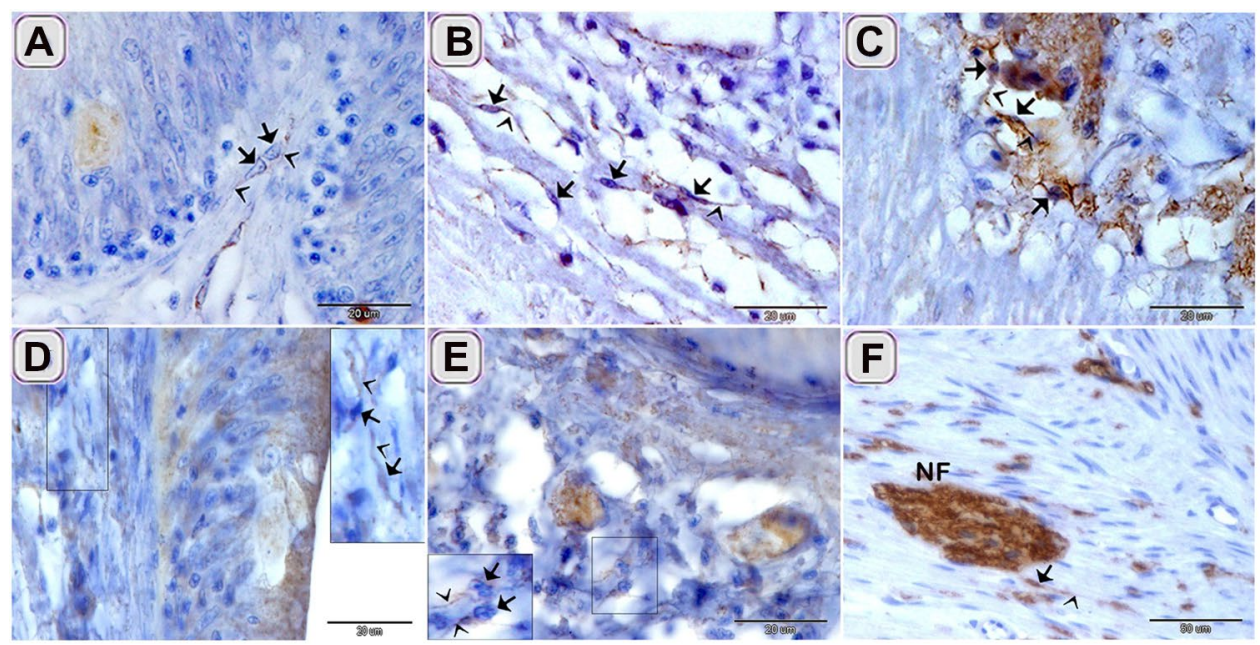

Figure 10. Immunohistochemical staining of the intestinal blub using desmin and S100-protein counter stain by HX. Immunostained paraffin sections of the intestinal blub for desmin (A-C) and S100-protein (D-F). (A) desmin positive sub-epithelial TCS (arrows). (B) desmin positive TCs (arrows) in the lamina propria. (C) desmin positive TCs (arrows) between the muscle bundles. (D) S100-protein positive TCs (arrows) under the epithelium. (E) S100-protein positive TC (arrows) between the muscle bundles. (F) S100-protein positive TC (arrows) connected with nerve fiber (NF). Note: Telopodes (arrowheads).
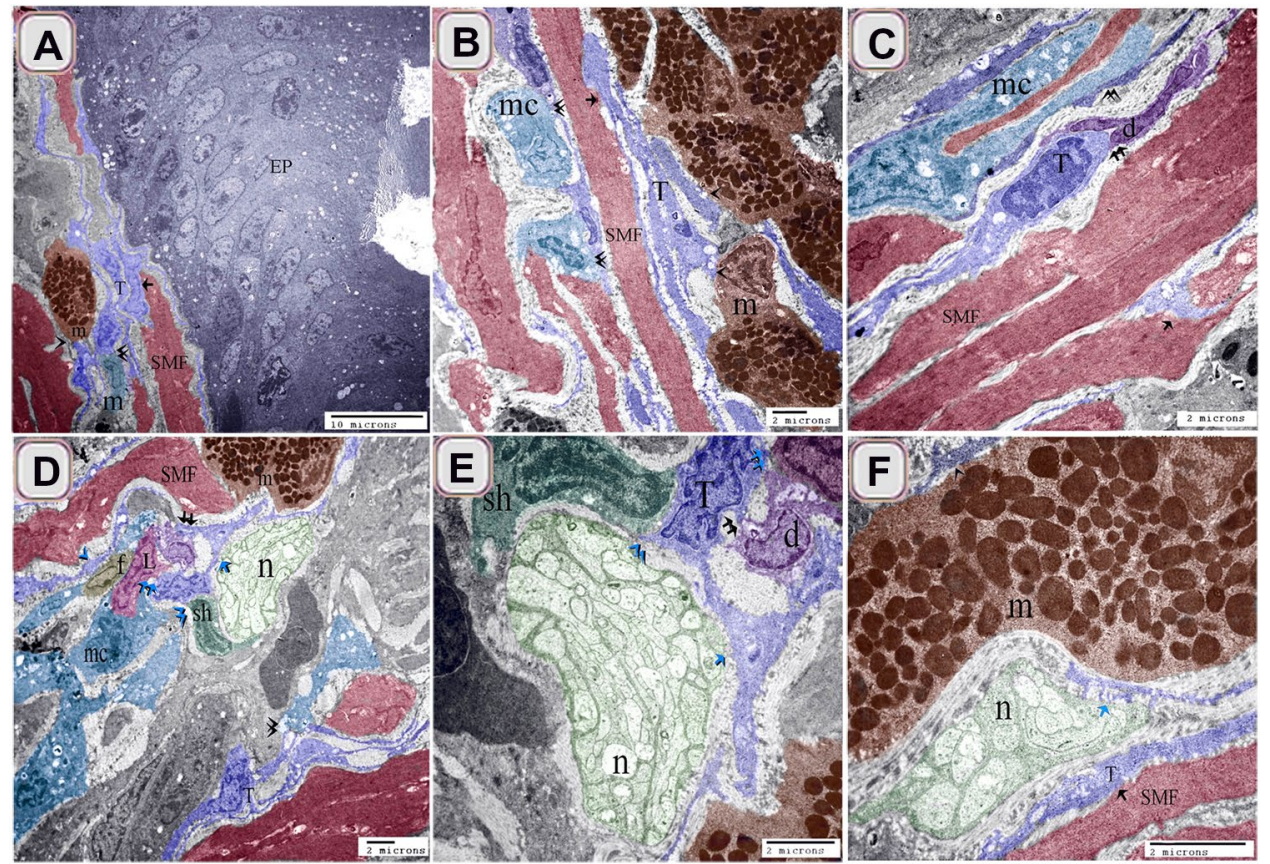

Figure 11. Relation of TCs with immune cells. (A) sub-epithelial TCS (T, blue color) and (B) TCS (T, blue color) in the lamina propria established a $3 \mathrm{D}$ network that connected with macrophages, ( $\mathrm{mc}$, turquoise color, double arrowhead), mast cells ( $\mathrm{m}$, brown color, arrowhead), and smooth muscle fibers (SMF, reddish brown, arrow). Note: epithelium (EP, gray color). (C) TCS (T, blue color) in the lamina propria connected with dendritic cells (d, violet color), macrophage ( $\mathrm{mc}$, double arrowhead), and smooth muscle fibers (SMF, reddish-brown) .(D-F) Tcs (T, blue color) connected with Schwann cell (sh, dark green color, blue double black arrowheads), nerve fibers (n, blue arrow), lymphocyte (L. blue double arrow), and dendritic cells (violet color, double arrow). Note mast cells (brown color, m), smooth muscle fibers (reddish-brown color, SMF), fibroblast (f). 


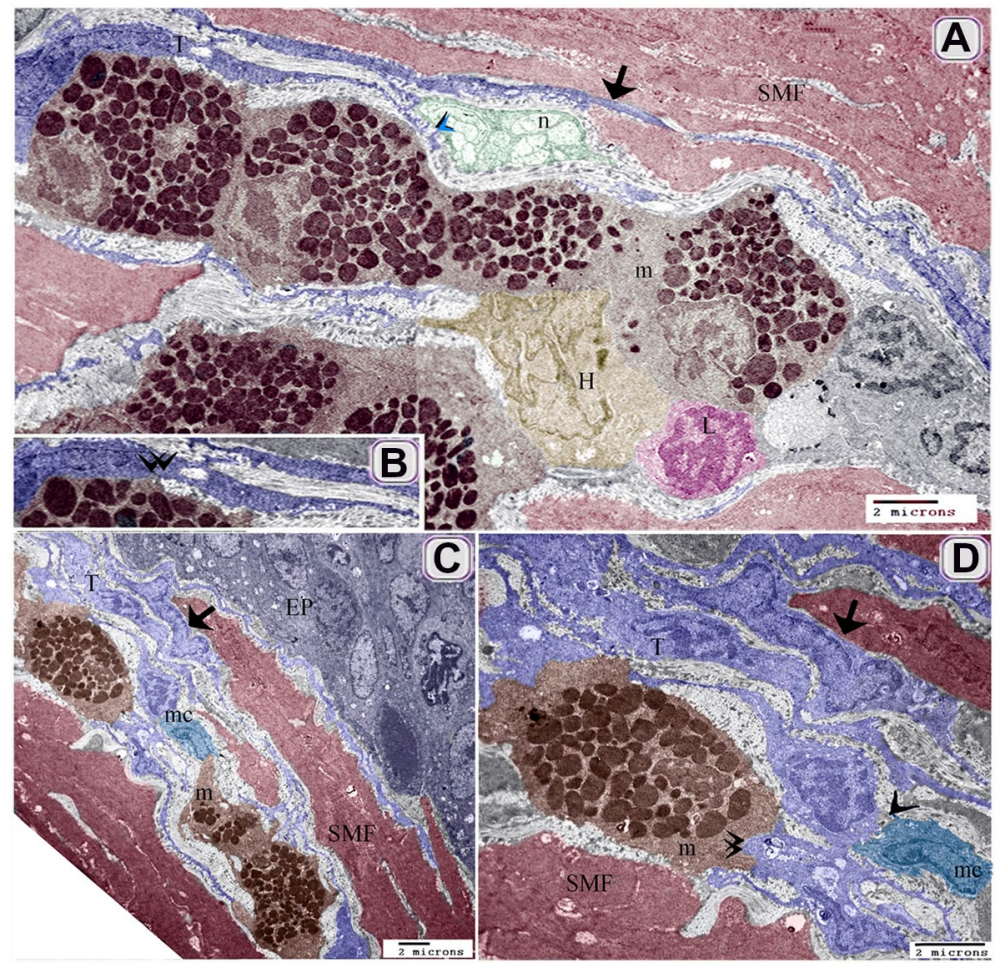

Figure 12. Relation of TCs with immune cells TEM. (A, B) TCS (T, blue color) connected with mast cells (m, brown color, and arrowhead), smooth muscle fibers (SMF, reddish-brown, arrow), nerve fibers (n, green color, blue arrow). Note heterophil (H, light brown), and lymphocyte (L, pink color). (C, D) sub epithelial TCS (T) established a 3D network that connected with macrophages $(\mathrm{mc}$, the arrowhead), mast cells ( $\mathrm{m}$, brown color, double arrowhead), and smooth muscle fibers (SMF, reddish-brown color, arrow). Note epithelium (EP).

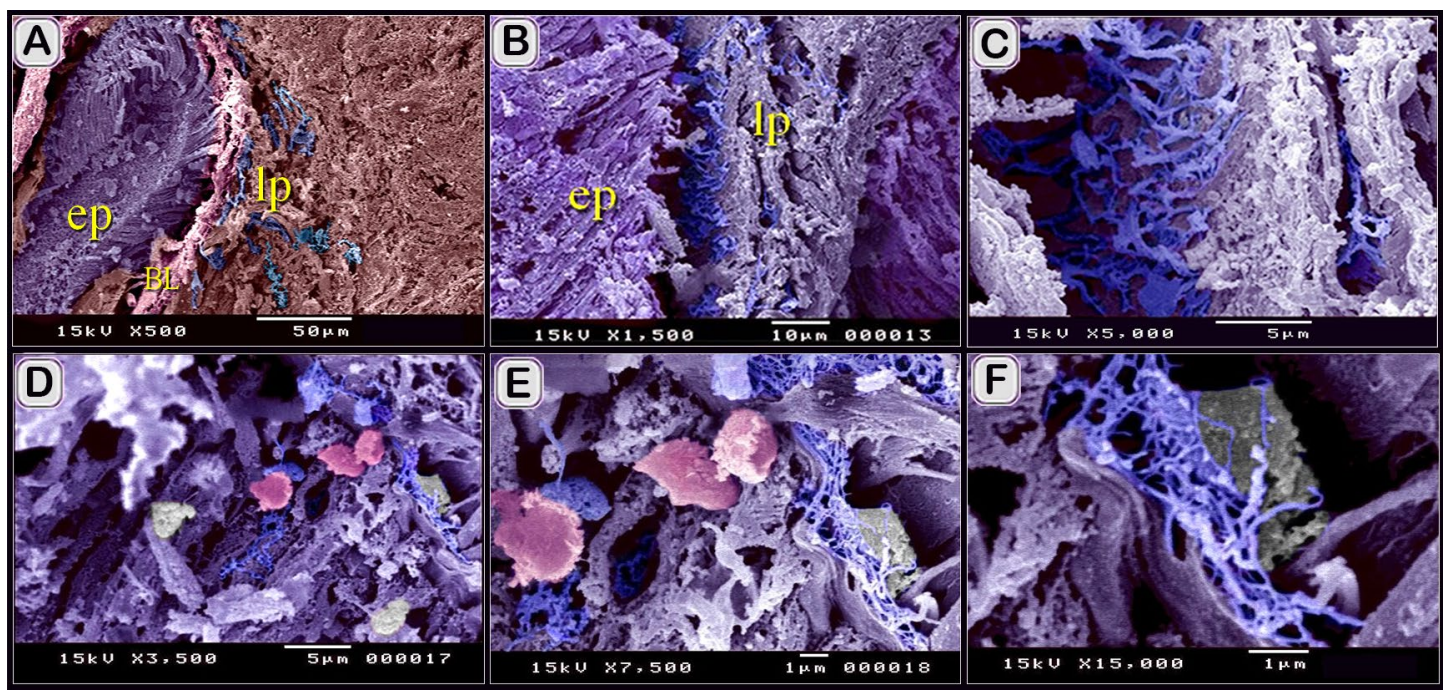

Figure 13. Scanned mucosal TC. (A) general view of the scanned sample of the intestinal blub. Note the epithelium (ep, violet color), lamina propria (lp), muscle (brown color). Basal lamina (Bl, pink color), TCs (blue colored). (B, C) sub epithelial TC sheet (blue colored). Note the epithelium (ep, violet color), lamina propria (lp). (D-F) TCs (arrowheads) in the lamina propria make contact with rodlet cells (pink colored) within the epithelium, were bear-shaped, and the capsules were smooth.

contact with TCs, such as lymphocytes, plasma cells, eosinophils, basophils, macrophages, and mast cells ${ }^{8,27,81}$. Moreover, in vitro studies support TCs role in the regulation of immune response via the paracrine pathway. Uterine TCs have a major role in the activation of peritoneal macrophages. Mouse peritoneal macrophages acquired abundant pseudopodia and cytoplasmic secretory granules when co-cultured with TCs. Macrophages increase the section of several cytokines including TNF- $\alpha$, IL1-R1, and IL-10, but not TGF- $\beta 1$, IL-1 $\beta$, IL-23a, and 


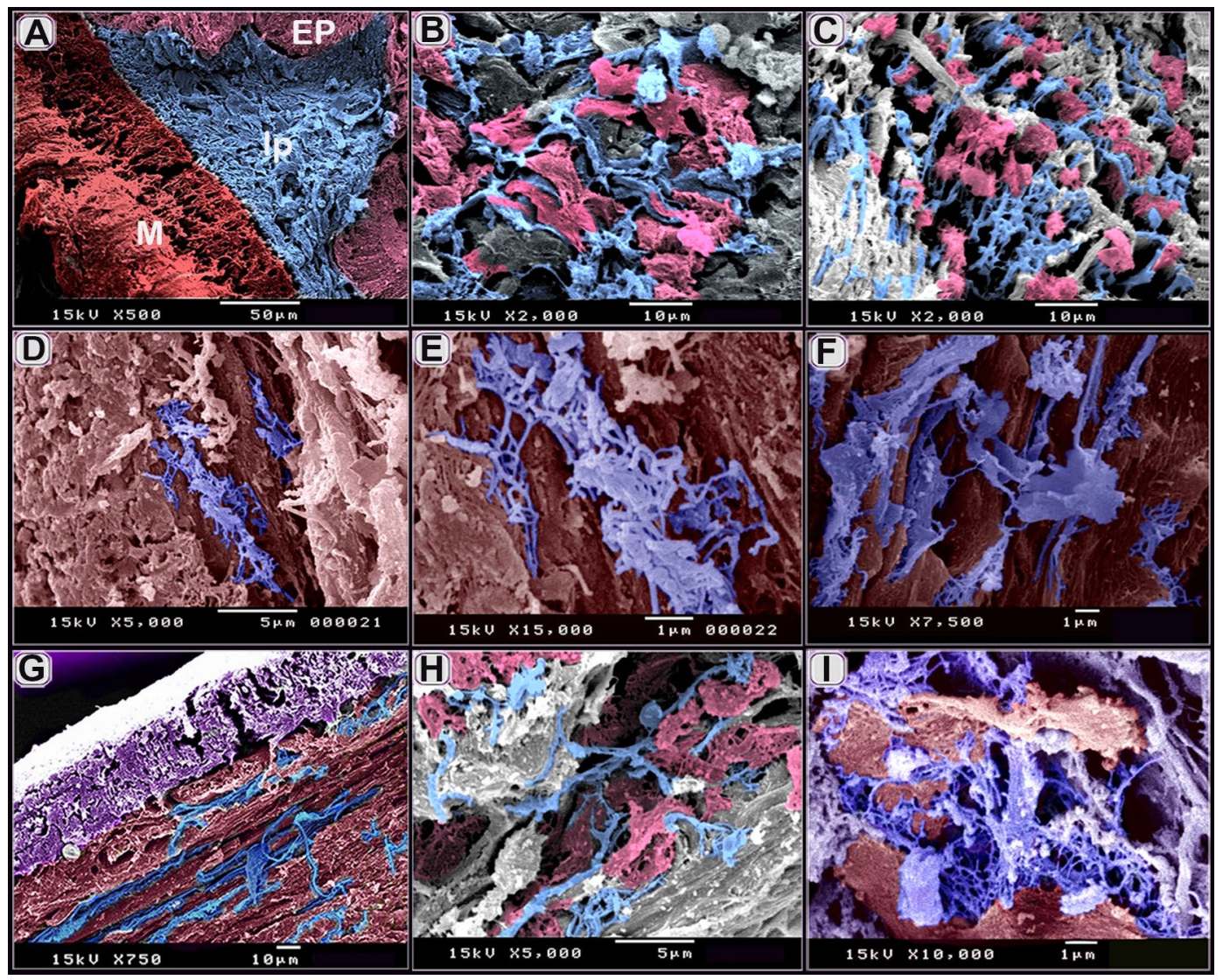

Figure 14. Scanned muscular TCs. (A) scanned sample of the intestinal blub. Note the epithelium (ep), lamina propria (lp, telocytes (blue color), muscle ( $\mathrm{m}$, reddish brown color). (B, C) TCs network (blue colored) in the lamina propria. Note connected teloped (pink colored). (D-F) TCs (blue colored) between muscle bundles (red colored). (G, I) TC network between muscle fibers (brown colored). Note connetced teloped (pink colored). (H) TCs (blue color) in serosa.

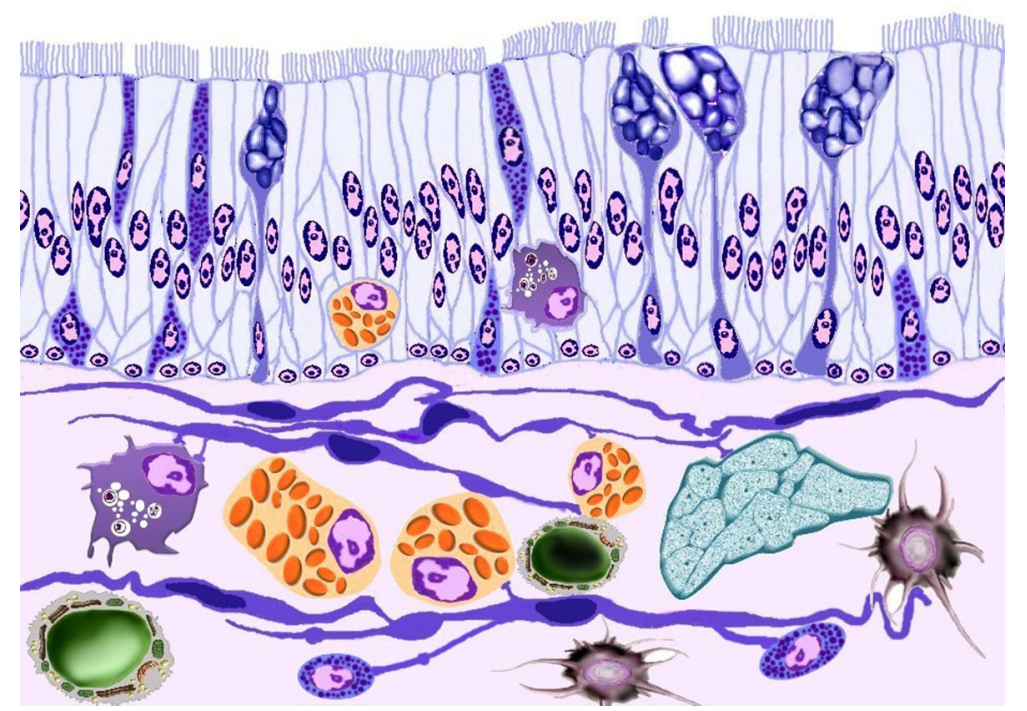

Figure 15. An illustration showed the relation between TCs and other cells in the intestinal blub. TCs established contact with neuroendocrine cells (violet granular cells), nerve fibers (green colored), masts cells (orange colored), dendritic cells (brown colored), lymphocytes (green colored), macrophages (violet colored). 
IL-18, suggesting potential role in immunoregulatory and immunosurveillance mechanism ${ }^{82}$. TCs implicated to triggers tissue changes in dendritic-linked immune disease ${ }^{83}$.

C-kit or CD117 is strong markers of stem cells ${ }^{84,85}$. CD117 interacts with the ligand stem cell factor to stimulate cellular differentiation, proliferation, chemotaxis, cell adhesion, and apoptosis ${ }^{86}$. Telocytes are commonly express c-kit. c-kit is a member of the transmembrane kinase receptor. c-kit plays a critical role in TCs functions ${ }^{87}$. $\mathrm{C}$-kit tyrosine kinase is involved in the transduction of intracellular signaling ${ }^{88}$. Telocytes are categorized depending on c-kit immunoaffinity. Some TCs were CD34-positive/c-kit-negative in the human bladder ${ }^{89}$.

TCs had high affinity for immunostaining of cytoskeletal components, particularly the intermediate filaments desmin, and S-100 protein. The term S-10 protein is used based on the physical properties of the protein that is soluble in a $100 \%$ saturated solution of ammonium sulfate at neutral $\mathrm{pH}^{90}$. S-100 proteins are a member of $\mathrm{Ca}^{+2}$-binding proteins. They function as $\mathrm{Ca}^{+2}$ sensor proteins and promote $\mathrm{Ca}^{+2}$ signal transduction. S-100 proteins have intracellular and extracellular functions. They combine into specific proteins in cells, e.g., desmin, tubulin, and others ${ }^{91}$. S-100 proteins bind to different types of cell receptors ${ }^{92,93}$. S-100 proteins are implicated in the regulation of cell dynamics and shape through the interaction of cytoskeletal proteins including microfilaments, microtubules, and intermediate filaments ${ }^{94,95}$. They interact with proteins that act as protein Players that regulate the secretory pathway ${ }^{93}$. Thus, S-100 proteins may participate in the regulation of the TC morphology and the secretory functions of TCS. TCS express desmin in the intestinal bulb of the Grass carp. Desmin is a member of the intermediate filament. As the other cytoskeletal elements, desmin has a supportive function to the cells ${ }^{96}$. TCs express desmin in the uterine tube of bovine ${ }^{8}$.

\section{Conclusion}

The current study presented the relation of TCs with different types of immune cells in the intestinal bulb of the Grass carp. We suggest that TCs may have an essential role to maintain intestinal immunity. TCs share histochemical and immunological features of endocrine cells. This may reveal that TCS had endocrine properties. Further studies should investigate TCs proteins profile linked to endocrine function.

\section{Data availability}

All data generated or analyzed during this study are included in this published article and its Supplementary Information files.

Received: 3 April 2020; Accepted: 21 July 2020

Published online: 20 August 2020

\section{References}

1. Gherghiceanu, M. \& Popescu, L. Cardiac telocytes-their junctions and functional implications. Cell Tissue Res. 348(2), 265-279 (2012).

2. Sun, X. et al. Differences in the expression of chromosome 1 genes between lung telocytes and other cells: mesenchymal stem cells, fibroblasts, alveolar type II cells, airway epithelial cells and lymphocytes. J. Cell. Mol. Med. 18(5), 801-810 (2014).

3. Zheng, Y. et al. Protein profiling of human lung telocytes and microvascular endothelial cells using iTRAQ quantitative proteomics. J. Cell. Mol. Med. 18(6), 1035-1059 (2014).

4. Zheng, Y. et al. Genetic comparison of mouse lung telocytes with mesenchymal stem cells and fibroblasts. J. Cell. Mol. Med. 17(4), 567-577 (2013).

5. Jiang, X.-J. et al. An in vitro investigation of telocytes-educated macrophages: morphology, heterocellular junctions, apoptosis and invasion analysis. J. Transl. Med. 16(1), 85 (2018).

6. Maria-Giuliana, V., Daniele, B. \& Maria-Simonetta, F.-P. Telocytes contribute as cell progenitors and differentiation inductors in tissue regeneration. Curr. Stem Cell Res. Ther. 11(5), 383-389 (2016).

7. Shoshkes-Carmel, M. et al. Subepithelial telocytes are an important source of Wnts that supports intestinal crypts. Nature 557(7704), 242-246 (2018).

8. Abd-Elhafeez, H. H. \& Soliman, S. A. New description of telocyte sheaths in the bovine uterine tube: an immunohistochemical and scanning microscopic study. Cells Tissues Organs. 203(5), 295-315 (2017).

9. Mitrofanova, L. et al. Morphological and immunophenotypic characterization of perivascular interstitial cells in human glioma: telocytes, pericytes, and mixed immunophenotypes. Oncotarget. 11(4), 322 (2019).

10. Veress, B. \& Ohlsson, B. Spatial relationship between telocytes, interstitial cells of Cajal and the enteric nervous system in the human ileum and colon. J. Cell. Mol. Med. 24(6), 3399-3406 (2020).

11. Bahar Halpern, K. et al. Lgr5+ telocytes are a signaling source at the intestinal villus tip. Nat. Commun. 11(1), 1936 (2020).

12. Soliman, S. A. Telocytes during organogenesis: relations to nephrogenic cords in mesonephros of quail embryos. Histol. Cytol. Embryol. 1(4), 1-6 (2017).

13. Yang, P. et al. Ultrastructural identification of telocytes in the muscularis of chicken ileum. Exp. Ther. Med. 10(6), 2325-2330 (2015).

14. Gandahi, N. S. et al. Identification of telocytes in the pancreas of turtles-a role in cellular communication. Int. J. Mol. Sci. 21(6), $2057(2020)$.

15. Ge, T., Ye, Y. \& Zhang, H. Ultrastructure of telocytes, a new type of interstitial cells in the myocardium of the Chinese giant salamander (Andrias davidianus). Eur. J. Histochem. 63(2), 3021 (2019).

16. Abdel-latief Soliman, S. M. and Ali Emeish, W. F. (2017) Morphological Alternations of Intraepithelial and Stromal Telocytes in Response to Salinity Challenges. bioRxiv 115881.

17. Mazzoni, T., Ribeiro Viadanna, R. \& Quagio-Grassiotto, I. Presence, localization and morphology of TELOCYTES in developmental gonads of fishes. J. Morphol. 280, 654-665 (2019).

18. Pulze, L. et al. A new cellular type in invertebrates: first evidence of telocytes in leech Hirudo medicinalis. Sci. Rep. 7(1), 1-12 (2017).

19. Zheng, Y. et al. Telocytes in trachea and lungs. J. Cell. Mol. Med. 15(10), 2262-2268 (2011).

20. Tay, H., Vandecasteele, T. \& Van den Broeck, W. Identification of telocytes in the porcine heart. Anat. Histol. Embryol. 46(6), 519-527 (2017).

21. Li, H. et al. Scanning electron microscope evidence of telocytes in vasculature. J. Cell. Mol. Med. 18(7), 1486-1489 (2014).

22. Zheng, Y. et al. Telocytes in the urinary system. J. Transl. Med. 10, 188-188 (2012). 
23. Rosa, I. et al. Telocytes constitute a widespread interstitial meshwork in the lamina propria and underlying striated muscle of human tongue. Sci. Rep. 9(1), 5858 (2019).

24. Vannucchi, M. G. et al. Telocytes express PDGFRa in the human gastrointestinal tract. J. Cell. Mol. Med. 17(9), 1099-1108 (2013).

25. Pawlicki, P. et al. Telocytes in the mouse testicular interstitium: implications of G-protein-coupled estrogen receptor (GPER) and estrogen-related receptor (ERR) in the regulation of mouse testicular interstitial cells. Protoplasma. 256(2), 393-408 (2019).

26. Janas, P. et al. Telocytes in the female reproductive system: an overview of up-to-date knowledge. Adv. Clin. Exp. Med 27, 559-565 (2018).

27. Abdel-Maksoud, F. M., Abd-Elhafeez, H. H. \& Soliman, S. A. Morphological changes of telocytes in camel efferent ductules in response to seasonal variations during the reproductive cycle. Sci. Rep. 9(1), 4507 (2019).

28. Zhang, B. et al. Telocytes: a potential defender in the spleen of Npcl mutant mice. J. Cell. Mol. Med. 21(5), 848-859 (2017).

29. Zhou, Q. et al. Cardiac telocytes are double positive for CD34/PDGFR-alpha. J. Cell. Mol. Med. 19(8), 2036-2042 (2015).

30. Yousef, M. S. et al. Ovulatory follicular fluid induces sperm phagocytosis by neutrophils, but oviductal fluid around oestrus suppresses its inflammatory effect in the buffalo oviduct in vitro. Mol. Reprod. Dev. 86(7), 835-846 (2019).

31. Harris, H. F. On the rapid conversion of haematoxylin into haematein in staining reactions. J. Appl. Microsc. Lab. Methods 3(3), $777-780$ (1900).

32. Suvarna, K., Layton, C. \& Bancroft, J. Bancroft's Theory and Practice of Histological. Techniques (Elsevier, Churchill Livingstone, 2013).

33. Crossmon, G. a modification of Mallory's connective tissue stain with discussion of the principle involved. Anat. Rec. 69, 33-38 (1937).

34. Mallory, F. B. The anilin blue collagen stain. Stain Technol. 11(3), 101-102 (1936).

35. McManus, J. Histological and histochemical uses of periodic acid. Stain Technol. 23, 99-108 (1948).

36. Mowry, R. W. The special value of methods that color both acidic and vicinal hydroxyl groups in the histochemical study of mucins, with revised directions for the colloidal iron stain, and the use of Alcian blue 8GX and their combinations with the periodic acidSchiff reaction. 3. Ann. N.Y. Acad. Sci. 106, 402-442 (1963).

37. Weigert, C. Über eine methode zur färbung elastischer fasern. Zentralbl Pathol. 9, 289-292 (1898).

38. Van Gieson, I. Laboratory notes of technical method for the nervous system. N.Y. Med. J. 50, 57-60 (1889).

39. Grimelius, L. A silver nitrate stain for alpha-2 cells in human pancreatic islets. Acta Soc. Med. Ups. 73(5-6), 243-270 (1968).

40. Marsland, T. A., Glees, P. \& Erikson, L. B. Modification of the Glees silver impregnation for paraffin sections. J. Neuropathol. Exp. Neurol. 13(4), 587-591 (1954).

41. Chaco2589 from: https://www.quizlet.com/13184659/ht-08-connective-and-muscle-tissue-flash-cards/ (2012).

42. Gates, L., Adler, R. R. \& Elangbam C. S. Osmium tetroxide post-fixation and periodic acid-Schiff dual-staining technique to demonstrate intracellular lipid and glycogen in the mouse liver section - a novel method for co-visualization of intracellular contents in paraffin-embedded tissue, J Histotechnol, 39(1), 2-7 (2016). https://doi.org/10.1080/01478885.2015.1106072.

43. Abd-Elhafeez, H. H. et al. Migratory activities and stemness properties of rodlet cells. Microsc. Microanal. https://doi.org/10.1017/ S1431927620001828.

44. Hoff, R. G., Newman, D. E. \& Staneck, J. L. Bacteriuria screening by use of acridine orange-stained smears. J. Clin. Microbiol. 21(4), 513-516 (1985).

45. El-Bab, M. F. et al. Identification of tracheal cartilage canals in camel: tracheal cartilage canals in camel. PSM Vet. Res. 4(3), 99-105 (2019).

46. Mahmoud, M. A. M., Zaki, R. S. \& Abd-Elhafeez, H. H. An epifluorescence-based technique accelerates risk assessment of aggregated bacterial communities in carcass and environment. Environ. Pollut. 260(113950), 113950 (2020).

47. Soliman, S. A. Morphological and histochemical description of quail feather development. Anat. Rec. https://doi.org/10.1002/ar. 24276 (2019).

48. Soliman, S. A., Kamal, B. M. \& Abd-Elhafeez, H. H. Cellular invasion and matrix degradation, a different nature of matrix degrading-cells in the cartilage of catfish (Clarias gariepinus) and Japanese Quail embryos (Coturnix coturnix japonica). Microsc. Microanal. 25(5), 1283-1292 (2019).

49. Clerc, S. \& Barenholz, Y. A quantitative model for using acridine orange as a transmembrane pH gradient probe. Anal. Biochem. 259(1), 104-111 (1998).

50. Nadrigny, F. et al. Systematic colocalization errors between acridine orange and EGFP in astrocyte vesicular organelles. Biophys. J. 93(3), 969-980 (2007).

51. Soliman, S. A. et al. Morphological and histochemical characterization of the dermal plates of pleco (Hypostomus plecostomus). Microsc. Microanal. 26, 551-566 (2020).

52. Hsu, S. M., Raine, L. \& Fanger, H. Use of avidin-biotin-peroxidase complex (ABC) in immunoperoxidase techniques: a comparison between ABC and unlabeled antibody (PAP) procedures. J. Histochem. 29, 577-580 (1981).

53. Soha Soliman, A., Hanan Hassan, A. \& Enas, A. A new mechanism of cartilage growth in mammals "involvement of CD117 positive undifferentiated cells in interstitial growth". MJ Cyto 1(1), 1 (2017).

54. Kammerer, U. et al. A new rapid immunohistochemical staining technique using the EnVision antibody complex. J. Histochem. Cytochem. 49(5), 623-630 (2001).

55. Sobhy, W. et al. Assessment of proliferative activity by proliferative cell nuclear antigen (PCNA) and anti-bromodeoxyuridine (BrdU) immunolabeling in the tissues of Japanese Eels (Anguilla japonica). Turk. J. Fish. Aquat. Sci. 14, 413-419 (2014).

56. Karnovsky, M. J. A formaldehyde-glutaraldehyde fixative of high osmolarity for use in electron microscopy. J. Cell. Biol. 27, 137A-138A (1965).

57. Abd-Elhafeez, H. H. \& Soliman, S. A. Origin of rodlet cells and mapping their distribution in ruby-red-fin shark (rainbow shark) Epalzeorhynchos frenatum (Teleostei: Cyprinidae): light, immunohistochemistry and ultrastructure study. J. Cytol. Histol. 7, 435 (2016).

58. Soliman, S. A., Ahmed, Y. A. \& Abdelsabour-Khalaf, M. Histogenesis of the stomach of the pre-hatching quail: a light microscopic study. Anat. Sci. Int. 91(4), 407-418 (2016).

59. Soliman, S. and Emeish, W. (2017) Morphological Alternations of Intraepithelial and Stromal Telocytes in Response to Salinity Challenges. bioRxiv.

60. Soliman, S. A. Identification of Merkel receptors sheet in quail beak. Cytol. Histol. Int. J. 3(1), 000107 (2019).

61. Reynolds, E. G. The use of lead citrate at high $\mathrm{pH}$ as an electron-opaque stain in electron microscopy. J. Cell. Biol. 17, 208-212 (1963).

62. Lloyd, R. V. Morphology Methods: Cell and Molecular Biology Techniques (Springer, Berlin, 2001).

63. Soliman, S. A. \& Madkour, F. A. A comparative analysis of the organization of the sensory units in the beak of duck and quail. Histol. Cytol. Embryol. 1(4), 1-16 (2017).

64. Gross, C. A., Reddy, C. K. \& Dazzo, F. B. CMEIAS color segmentation: an improved computing technology to process color images for quantitative microbial ecology studies at single-cell resolution. Microb. Ecol. 59(2), 400-414 (2010).

65. Mustafa, F. E. A. \& El-Desoky, S. M. M. Architecture and cellular composition of the spleen in the Japanese Quail (Coturnix japonica). Microsc. Microanal. 12, 1-10 (2020).

66. Soliman, S. A. \& Abd-Elhafeez, H. H. Mesenchymal cells in cartilage growth and regeneration "an immunohistochemical and electron microscopic study. J. Cytol. Histol. https://doi.org/10.4172/2157-7099.1000437 (2016). 
67. Soliman, S. A. \& Abd-Elhafeez, H. H. Are C-KIT, MMP-9 and Type II collagen positive undifferentiated cells involved in cartilage growth? A description of unusual interstitial type of cartilage growth. J. Cytol. Histol. https://doi.org/10.4172/2157-7099.1000440 (2016).

68. Grover, T. R. et al. Vascular endothelial growth factor causes pulmonary vasodilation through activation of the phosphatidylinositol3-kinase-nitric oxide pathway in the late-gestation ovine fetus. Pediatr. Res. 52(6), 907-912 (2002).

69. Abd-Elkareem, M. Cell-specifc immuno-localization of progesterone receptor alpha in the rabbit ovary during pregnancy and afer parturition. Anim. Reprod. Sci. 180, 100-120 (2017).

70. Abdel-Hakeem, S. S., Mahmoud, G. A. \& Abdel-Hafeez, H. H. Evaluation and microanalysis of parasitic and bacterial agents of Egyptian fresh sushi, Salmo salar. Microsc. Microanal. 13, 1-11 (2019).

71. Mustafa, F.E.-Z.A. Putative primo-vascular system in rabbit placenta. J. Acupunct. Meridian Stud. 12(1), 20-24 (2019).

72. McIlwain, D. L. \& Hoke, V. B. The role of the cytoskeleton in cell body enlargement, increased nuclear eccentricity and chromatolysis in axotomized spinal motor neurons. BMC Neurosci. 6(1), 19 (2005).

73. Al-Hayani, A. et al. Does vitamin E protect against sodium fluoride toxicity on the cerebellar cortex of albino rats?. Middle East J. Sci. Res. 16, 1019-1026 (2013).

74. Young, B. et al. Wheater's Functional Histology (Elsevier, Amsterdam, 2006).

75. Yang, P. et al. Ultrastructural identification of different subtypes of interstitial cells of Cajal in the chicken ileum. Poult. Sci. 91, 1936-1940 (2012).

76. Al-Shboul, O. A. The importance of interstitial cells of cajal in the gastrointestinal tract. Saudi J. Gastroenterol. 19(1), 3-15 (2013).

77. Iino, S. \& Horiguchi, K. Interstitial cells of cajal are involved in neurotransmission in the gastrointestinal tract. Acta Histochem. Cytochem. 39(6), 145-153 (2006).

78. Sidney, L. E. et al. Concise review: evidence for CD34 as a common marker for diverse progenitors. Stem Cells 32(6), 1380-1389 (2014).

79. Rehfeld, J. F. \& Goetze, J. P. The post-translational phase of gene expression in tumor diagnosis. In Handbook of Immunohistochemistry and in Situ Hybridization of Human Carcinomas (ed. Hayat, M. A.) 23-32 (Academic Press, Cambridge, 2006).

80. Bandyopadhyay, G. K. \& Mahata, S. K. Chromogranin a regulation of obesity and peripheral insulin sensitivity. Front. Endocrinol. 8, 8-20 (2017).

81. Popescu, L. M. et al. The connective connection: interstitial cells of Cajal (ICC) and ICC-like cells establish synapses with immunoreactive cells. Electron microscope study in situ. J. Cell. Mol. Med. 9(3), 714-730 (2005).

82. Chi, C. et al. In vitro morphology, viability and cytokine secretion of uterine telocyte-activated mouse peritoneal macrophages. J. Cell. Mol. Med. 19(12), 2741-2750 (2015).

83. Manole, C. G., Gherghiceanu, M. \& Simionescu, O. Telocyte dynamics in psoriasis. J. Cell. Mol. Med. 19(7), 1504-1519 (2015).

84. Deng, W. (2010) Mesenchymal stem cells express c-kit. Circ. Res. 12, 107(10), e17 (2010). author reply e18. https://doi.org/10.1161/ CIRCRESAHA.110.230961.

85. Bornemann, A. \& Schmalbruch, H. Desmin and vimentin in regenerating muscles. Muscle Nerv. 15(1), 14-20 (1992).

86. Miettinen, M. \& Lasota, J. KIT (CD117): a review on expression in normal and neoplastic tissues, and mutations and their clinicopathologic correlation. Appl. Immunohistochem. Mol. Morphol. 13(3), 205-220 (2005).

87. Urban, L. et al. Telocytes (interstitial Cajal-like cells) in human Fallopian tubes. Bratisl Lek Listy 117(5), 263-267 (2016).

88. Liang, J. et al. The C-kit receptor-mediated signal transduction and tumor-related diseases. Int. J. Biol. Sci. 9(5), 435-443 (2013).

89. Vannucchi, M. G. et al. Telocytes subtypes in human urinary bladder. J. Cell. Mol. Med. 18(10), 2000-2008 (2014).

90. Zimmer, D. B. et al. The S100 protein family: history, function, and expression. Brain Res. Bull. 37(4), 417-429 (1995).

91. Donato, R. Functional roles of S100 proteins, calcium-binding proteins of the EF-hand type. Biochim. Biophys. Acta Mol. Cell. Res. 1450(3), 191-231 (1999)

92. Bresnick, A. R. S100 proteins as therapeutic targets. Biophys. Rev. 10(6), 1617-1629 (2018).

93. Xia, C. et al. S100 proteins as an important regulator of macrophage inflammation. Front. Immunol. 8, 1908 (2018).

94. Sorci, G. et al. Association of S100B with intermediate filaments and microtubules in glial cells. Biochim. Biophys. Acta Mol. Cell. Res. 1448(2), 277-289 (1998).

95. Huang, S. C., Soong, H. K. \& Kowal, V. O. Microfilaments, microtubules, and intermediate filaments in cultured corneal fibroblasts. Cornea 10(2), 110-120 (1991).

96. Paulin, D. \& Li, Z. Desmin: a major intermediate filament protein essential for the structural integrity and function of muscle. Exp. Cell. Res. 301(1), 1-7 (2004).

\section{Author contributions}

H.H.A.-E., A.S.A.-E., and S.A.S. designed the research study. H.H.A.-E., A.S.A.-E., and S.A.S. contributed to the analysis and interpretation of data. H.H.A.-E., A.S.A.-E., and S.A.S. arranged the images. H.H.A.-E., A.S.A.-E., and S.A.S. wrote the paper. All authors have read and approved the final version of the manuscript.

\section{Competing interests}

The authors declare no competing interests.

\section{Additional information}

Supplementary information is available for this paper at https://doi.org/10.1038/s41598-020-70032-y.

Correspondence and requests for materials should be addressed to H.H.A.-E.

Reprints and permissions information is available at www.nature.com/reprints.

Publisher's note Springer Nature remains neutral with regard to jurisdictional claims in published maps and institutional affiliations. 
(c) (i) Open Access This article is licensed under a Creative Commons Attribution 4.0 International cc) License, which permits use, sharing, adaptation, distribution and reproduction in any medium or format, as long as you give appropriate credit to the original author(s) and the source, provide a link to the Creative Commons license, and indicate if changes were made. The images or other third party material in this article are included in the article's Creative Commons license, unless indicated otherwise in a credit line to the material. If material is not included in the article's Creative Commons license and your intended use is not permitted by statutory regulation or exceeds the permitted use, you will need to obtain permission directly from the copyright holder. To view a copy of this license, visit http://creativecommons.org/licenses/by/4.0/.

(C) The Author(s) 2020 